\title{
NENHUMA DIVERGÊNCIA METAFÍSICA SEM INCOMPATIBILIDADE LÓGICA ${ }^{1}$
}

\author{
Daniel Durante ${ }^{2}$
}

\begin{abstract}
O objetivo deste artigo é defender a incompatibilidade lógica das posições divergentes como critério para caracterização dos desacordos genuinamente metafísicos. Ou seja, pretendo defender que uma disputa específica é um desacordo metafísico legítimo apenas quando as posições adversárias são regidas por lógicas distintas. Se correto, este critério poderia não apenas ajudar a distinguir disputas meramente verbais de debates metafísicos genuínos, como também forneceria um argumento contra o deflacionismo da metafísica, garantindo a sua substancialidade e relevância. Pretendo esclarecer o critério, apresentar seus fundamentos e compromissos filosóficos mais básicos, dar algumas motivações tanto lógicas quanto metafísicas para sua adoção, além de alguns exemplos de sua aplicação.
\end{abstract}

\section{Introdução}

Costumamos classificar como metafísicas questões cujas respostas envolvem uma caracterização da estrutura mais geral da realidade. Os objetos materiais, por exemplo, existem completamente em cada instante do tempo, ou existem apenas parcialmente a cada instante, tendo partes temporais? Os números existem independentemente de nosso pensamento ou são constituídos por nossa atividade mental? Estas questões costumam ser consideradas metafísicas porque suas respostas exigem esclarecimentos sobre como a realidade é estruturada e o que a compõe. Respostas à primeira exigem uma concepção sobre o que é o tempo e de que modo a sua passagem afeta e participa da estrutura da realidade, e respostas à segunda exigem uma concepção sobre se a estrutura da realidade tem ou não lugar para coisas que entendemos com o pensamento, mas que não têm materialidade, tais como os números.

Por serem tão gerais, as perguntas metafísicas como estas nos deixam, muitas vezes, com a sensação de que qualquer resposta que dermos a elas não terá efeito algum para fora dos limites da própria discussão. Afinal, dois mais dois continuará sendo quatro, sejam os números construções mentais ou objetos abstratos que existem fora de nossas mentes. O computador no qual escrevo estas palavras agora não se altera, não fica mais rápido ou mais lento, melhor ou pior, quando considero que ele está aqui a minha frente em toda sua existência, ou quando considero que o que tenho a minha frente é apenas uma pequena parte temporal do computador, cuja existência completa inclui suas partes passadas e futuras.

Estas considerações nos levam a perguntar: haverá alguma substancialidade nos debates metafísicos ou todos eles são mera perda de tempo sem qualquer conexão com o mundo do lado de fora dos departamentos de filosofia? Será que nossas concepções sobre a estrutura mais geral da realidade têm alguma consequência que extrapola os limites das

\footnotetext{
1 An English version of this article is available at: http://tiny.cc/b4y $47 y$.

2 Departamento de Filosofia, UFRN. Email: durante10@gmail.com.

DOI : 10.21452/LnA_serie_n_v01_book_seminario-logica-no-aviao-2013-2018_daniel-durante_p.149-186
} 
próprias discussões? Se eu e você divergirmos sobre o papel da mente na consitutição da realidade matemática, será que esta nossa divergência terá alguma influência na própria matemática ou em suas aplicações ou nos demais campos de nossas vidas?

A maioria das pessoas comuns, dos cientistas e até alguns filósofos consideram que a alternativa da irrelevância e da perda de tempo é a correta. Mas mesmo os que apreciam a metafísica, muitas vezes têm dúvidas sobre se uma suposta disputa específica é de fato relevante e substantiva ou é apenas um desacordo vocabular. Um buraco, por exemplo, tem independência ontológica, é algo que existe por si, ou sua existência é dependente de outra coisa, sendo ele apenas um aspecto da forma do material que o abriga? Ainda que eu seja alguém que considera as questões metafísicas substantivas e relevantes, eu não sou por causa disso obrigado a achar que todas as discussões supostamente metafísicas são de fato metafísicas. Talvez este assunto sobre buracos não seja uma questão metafísica genuína. Talvez ele seja um mero desacordo vocabular e não um problema que mereça o rótulo de problema metafísico.

E ainda que eu considere a metafísica relevante e também considere relevante e não meramente vocabular uma determinada questão específica, como saber se esta questão pertence mesmo ao campo teórico da metafísica? A definição que apresentei no início, de que as questões metafísicas são aquelas cujas respostas envolvem uma caracterização da estrutura mais geral da realidade, é muito ampla e vaga para funcionar como um critério. Haveria algum modo mais preciso de caracterizar as questões e debates metafísicos?

Façamos uma reorganização das questões até agora lançadas. A primeira e principal delas é a seguinte:

(1) A metafísica como disciplina tem alguma substancialidade ou as suas questões são irrelevantes para todos os assuntos fora de seus limites teóricos?

Um modo bastante efetivo de responder à questão sobre a relevância e substancialidade de qualquer disciplina é analisar se as divergências teóricas internas à disciplina têm consequências externas, fora de seus limites teóricos. Se uma divergência teórica provocar outras divergências externas ao contexto teórico em que ela ocorreu, então esta divergência não é irrelevante. Não é um mero desacordo vocabular inofensivo, mas uma divergência substantiva que se espalha para outros assuntos. E se uma divergência teórica afeta outros assuntos, então a disciplina, a área de estudos em que esta divergência ocorre não será ela própria uma disciplina irrelevante.

Suponha, por exemplo, que eu e você tenhamos diferentes concepções filosóficas sobre o conceito de indivíduo humano. Suponha que divirjamos sobre o que caracteriza um indivíduo humano. Suponha, ainda, que de acordo com o meu modo de entender o assunto, um embrião de poucas semanas não seja ainda classificado como um indivíduo humano. O embrião não atende todos os critérios que minha concepção do que seja um indivíduo humano requer. E suponha que de acordo com o seu modo de entender, o mesmo embrião atende os seus critérios e é, por isso, caracterizado por você como um indivíduo humano. Então esta nossa divergência filosófica sobre como caracterizar um indivíduo humano nos leva a divergir sobre se um embrião de poucas semanas é ou não um indivíduo humano. Do mesmo modo, uma divergência que pudéssemos ter sobre o modo como as coisas materiais existem através do tempo poderia nos levar a divergir sobre se o computador em que digito estas palavras está completamente em minha frente, agora, ou se estou diante apenas de uma pequena parte temporal dele.

Uma consequência de nossa divergência sobre o que caracteriza um indivíduo humano é que se de acordo com o meu critério um embrião de poucas semanas não é um indivíduo 
humano, então eu tenho condições de defender a moralidade e legalidade do aborto sem contradizer o princípio geral de que todo o indivíduo humano tem direito à vida. Já você, ao considerar o embrião como um indivíduo humano, não tem como defender a moralidade e legalidade do aborto sem contradizer o mesmo princípio. Nossa divergência sobre o que caracteriza um indivíduo humano provoca, então, outras divergências exteriores ao seu contexto teórico, já que por causa dela vamos divergir também sobre a moralidade e a legalidade do aborto. Por causa dela divergiremos sobre ética, direito, políticas de saúde pública, e até nossas atitudes pessoais diante de situações específicas que envolvam o aborto ou sua possibilidade também divergirão. Este caso mostra que a disciplina filosófica que abriga nossa divergência sobre como entender o conceito de indivíduo humano é bastante relevante e substancial.

Do mesmo modo, com relação à nossa divergência metafísica sobre a relação entre a existência e a duração temporal, que nos levou a divergir sobre se o que tenho a minha frente é o computador em toda sua existência ou apenas uma parte temporal dele; se mostrarmos que esta divergência tem consequências exteriores à metafísica, se esta divergência levar a outras divergências na física, na engenharia, em outros assuntos, se ela se espalhar, então saberemos que a metafísica é relevante e substancial, porque teremos mostrado que divergências metafísicas têm consequências que extrapolam os seus próprios limites teóricos.

Deste modo, daremos uma resposta à questão (1) acima que garante substancialidade e relevância à metafísica se respondermos afirmativamente à seguinte questão:

(2) As divergências metafísicas têm consequências que extrapolam os limites teóricos da própria filosofia?

A metafísica não será uma perda de tempo irrelevante se mostrarmos que nossas divergências sobre questões metafísicas espalham-se e têm consequências em outras áreas externas ao âmbito das teóricas discussões filosóficas. Mas para que uma resposta à questão (2) possa fornecer uma resposta a adequada à questão (1) precisamos, primeiramente, de um critério para decidir quando uma divergência específica deve ou não ser considerada como sendo de natureza metafísica. Antes de responder à questão (2) precisamos, então, responder à seguinte questão:

(3) O que caracteriza uma proposta específica como pertencente à metafísica e uma divergência específica como divergência metafísica?

Minha proposta é utilizar o critério que intitula este artigo, nenhuma divergência metafísica sem incompatibilidade lógica, como uma caracterização das propostas e divergências metafísicas que responde à questão (3) de um modo que leva a uma resposta afirmativa da questão (2) e, por conseguinte, a uma resposta da questão (1) que assegura relevância e substancialidade à metafísica. Ao raciocinarmos de acordo com lógicas diferentes e incompatíveis, usamos diferentes padrões para justificar a verdade das sentenças. Se $\mathrm{P}_{1}, \ldots, \mathrm{P}_{\mathrm{n}} \vdash \mathrm{A}$ for um argumento válido de acordo com a lógica que eu uso, mas inválido na lógica que você usa, e se nós dois concordamos que todas as premissas $P_{1}, \ldots, P_{n}$ são verdadeiras, ainda assim nós poderemos discordar sobre a verdade de $A$. Para mim $A$ tem que ser verdadeira, pois em minha lógica $P_{1}, \ldots, P_{n}$ justificam sua verdade. Mas, para você, $A$ pode ser falsa, porque na sua lógica $P_{1}, \ldots, P_{n}$ não são suficientes para justificar a verdade de $A$. Nossa divergência lógica nos autoriza a discordar sobre o valor de verdade de $A$, que pode ser uma sentença de qualquer assunto. Então, ao demandarem desacordos 
lógicos, os desacordos metafísicos podem espalhar-se através da lógica e ter consequências em todos os demais assuntos sobre os quais raciocinamos. Os desacordos metafísicos serão, portanto, substanciais e relevantes.

O fundamento deste critério é a ideia de que os princípios lógicos de inferência constituem-se em (ou são contrapartidas de) princípios metafísicos, e que qualquer proposta metafísica específica é indissociável de uma proposta lógica específica, de modo que não é possível haver divergência metafísica legítima sem que haja também divergência ou incompatibilidade lógica. Esclarecer este critério e seu fundamento, e apresentar algumas justificativas lógicas e metafísicas para sua adoção, além de alguns exemplos de sua aplicação, são o objetivo deste artigo.

A proposta que aqui apresento possui forte inspiração em dois importantes filósofos do Século XX. Willard van Orman Quine e Michael Anthony Eardley Dummett. Esta inspiração é ao mesmo tempo positiva e crítica. Por um lado, aproprio-me de muitas ideias destes autores e, por outro lado, ao reconhecer os problemas que a literatura tem apontado nas abordagens de cada um deles, construo o critério como uma resposta ou reação a eles.

No restante do artigo, na Seção 2, antes de propriamente esclarecer e justificar o critério da incompatibilidade lógica, reflito sobre seus limites e sobre a dupla posição que ele ocupa enquanto uma tese em filosofia da lógica e uma tese metametafísica. Na Seção 3, apresento brevemente a proposta metodológica de Quine para a ontologia. Suas ideias de arregimentação e compromisso ontológico representam a primeira inspiração de nossa tese e constituem-se em seus primeiros passos. Na Seção 4, esclareço uma limitação do método quineano e inicio a explicação mais minuciosa do critério, que corresponderá a uma proposta de superação desta limitação. Na Seção 5, discuto a proposta de Dummett para o tratamento das diversas instâncias do debate entre realismo e antirrealismo, o que fornecerá tanto um exemplo de aplicação bem sucedida do critério da incompatibilidade lógica, quanto algumas motivações metafísicas para sua adoção. A abordagem de Dummett aos debates metafísicos representa a segunda fonte principal de inspiração para nossa abordagem. Na Seção 6, critico a tese tradicional da separação entre lógica e metafísica, e aprofundo os argumentos em favor da interpretação dos teoremas quantificacionais da lógica como princípios metafísicos. Na Seção 7, proponho a tese da generalidade absoluta como um critério de demarcação da lógica e reforço, com argumentos lógicos, a concepção dos princípios lógicos como princípios metafísicos. Na Seção 8, aplico o critério a uma controvérsia específica entre Kris McDaniel e Peter van Inwagen a respeito da univocidade ou não do ser, demonstrando que, neste caso, a controvérsia não se trata de uma divergência metafísica legítima. Finalmente, na Seção 9, termino o artigo com algumas breves considerações finais.

\section{Alcance e Limites: filosofia da lógica e metametafísica}

A partir da primeira metade do Século XX, a ideia de uma suposta neutralidade metafísica da lógica ganhou força e adeptos. Ela já estava presente nas Investigações Lógicas de Edmund Husserl (2015) e adquiriu notoriedade com as teses do Tractatus LogicoPhilosophicus de Ludwig Wittgenstein (2014) de que "o mundo é a totalidade dos fatos, não das coisas", e de que as verdades lógicas nada informam sobre os fatos, não têm conteúdo factual. Posteriormente, Rudolf Carnap (1969) deu forma definitiva a esta ideia e a utilizou para isolar e protejer a lógica das pesadas críticas deflacionistas que ele e os demais positivistas lógicos dirigiram à metafísica. Finalmente, com a adoção da lógica 
clássica de primeira ordem e das concepções de Alfred Tarski (1944) sobre verdade e consequência lógica como o padrão ortodoxo entre lógicos e filósofos, a tese da neutralidade metafísica da lógica tornou-se hegemônica e ubíqua.

Para ilustrar esta tese, costumo contar aos meus estudantes a fábula do meteorologista de um jornal local que, no primeiro dia de trabalho, não queria arriscar seu emprego com uma previsão do tempo errada e publicou em seu boletim: "amanhã, em Natal, choverá ou não choverá". Ele acertou a previsão, mas perdeu o emprego mesmo assim. A previsão "choverá ou não choverá" é tão geral que simplesmente é impossível de ser falsa. Chova ou faça sol ela está correta. Mas qual é a utilidade de uma previsão do tempo que, ainda que verdadeira, não nos ajuda a decidir se ao sair de casa pela manhã devemos ou não levar o guarda-chuva ou um casaco? Ao ganhar generalidade a previsão perdeu informação, e o pobre meteorologista, o emprego.

Por serem compatíveis com todas as possibilidades em que os fatos podem se dar, as verdades lógicas, tais como "choverá ou não choverá", estariam separadas deles e da realidade e seriam, por isso, verdades meramente analíticas. Elas não tocam os fatos e não nos ajudam a saber o que ocorrerá ou não ocorrerá. Ao nada nos informarem sobre a realidade, as verdades lógicas seriam metafisicamente neutras.

Apesar da predominância desta tese durante boa parte do Século XX, os principais filósofos ao longo da história anterior, de Aristóteles a Russell, passando pelos medievais, por Leibniz e por Frege, não concebiam a lógica como metafisicamente neutra. Para a surpresa de muitos lógicos contemporâneos os princípios da identidade, da contradição e do terceiro excluído, que contemporaneamente são conhecidos como os três princípios aristotélicos da lógica clássica (D’Ottaviano and Feitosa, 2003), não foram apresentados por Aristóteles como princípios lógicos ou princípios da razão. Foram apresentados como "os princípios mais certos aplicáveis a todas as coisas" (Metafísica, 1005b10-35) (Aristotle and McKeon, 1941). Ou seja, princípios metafísicos. Um indício deste fato é que os referidos princípios são propostos e detalhadamente tratados não nos textos lógicos de Aristóteles, agrupados pelos comentadores antigos no Organon, mas no Livro 4 da Metafísica. Lá eles aparecem como primeiros princípios da ciência do ser enquanto ser (metafísica) e, por isso, de todas as outras ciências (Smith, 2019).

Em Frege também podemos encontrar vestígios desta concepção metafísica da lógica. Ele considerava que só seria possível justificar a concepção de que as leis da lógica são leis prescritivas para o pensamento, se as entendêssemos de um modo mais fundamental como leis da verdade, ou leis que estabelecem o que é. Para explicar-se distinguiu dois sentidos para a palavra "lei". Num sentido, o das leis da natureza, uma lei estabelece o que é. Todas as ocorrências factuais sempre se conformam às leis da natureza. No outro sentido, o das leis morais ou civis, uma lei é uma prescrição que estabelece o que deve ser. Nem todas as ocorrências factuais se conformam com as leis morais ou civis. Como o pensamento é um processo mental, as leis sobre como o pensamento é estão no âmbito da psicologia, não da lógica. Então, quando se diz que as leis da lógica são leis do pensamento, a única possibilidade é de as entendermos como leis prescritivas para o pensamento.

Mas o que dá à lógica o poder de prescrever as regras do pensamento? A resposta de Frege foi identificar as leis da lógica com as leis da verdade, leis que no âmbito mais geral possível estabelecem o que é.

Qualquer lei que estabelece o que é pode ser concebida como prescrevendo que se deve pensar em conformidade com ela, e é, então, uma lei [prescritiva] do pensamento. (Frege and Furth, 1967, 12) 
Assim, o que dá à lógica o direito de prescrever o pensamento correto é, para Frege, o fato de as leis lógicas serem leis sobre o que é. Deste modo, para Frege, assim como para Aristóteles, as leis da lógica são leis sobre todas as coisas, sobre o que é. E, neste sentido, são leis metafísicas.

Nos dias atuais, com a explosão das propostas de lógicas não clássicas, a tese da neutralidade metafísica da lógica, apesar de ainda vigente e forte em muitos círculos, vem sendo regularmente e cada vez mais confrontada. ${ }^{3}$ Podemos talvez considerar que a sobrevivência ainda hoje da tese da neutralidade metafísica da lógica é uma das últimas e mais fortes influências do positivismo lógico na filosofia contemporânea.

O critério que pretendo apresentar, motivar e exemplificar e que intitula este artigo assume exatamente a antítese da neutralidade metafísica da lógica. Mais do que a sua não neutralidade metafisica, quero defender a ideia oposta de que os princípios lógicos de inferência são também princípios metafísicos, e que qualquer proposta metafísica específica é indissociável de uma proposta lógica específica, não sendo possível haver uma divergência metafísica sem a companhia de uma divergência lógica.

Antes de esclarecer e exemplificar seu conteúdo, vamos refletir um pouco sobre como entender a dupla natureza filosófica do critério que proponho. Ele inclui tanto uma tese em filosofia da lógica, quanto uma tese metafísica, ou metametafísica, como alguns filósofos preferem chamar as teses que lidam com a natureza e a metodologia das questões metafísicas (Tahko, 2015). No âmbito da filosofia da lógica, a tese que nosso critério carrega é bastante simples. Ela alia-se à tradição de Aristóteles e Frege e constitui-se na antítese da tese da neutralidade metafísica da lógica. Os princípios lógicos de inferência não são metafisicamente neutros. Ao contrário, eles são princípios metafísicos. Ao prescreverem as regras do pensamento, os princípios lógicos estabelecem obrigações e proibições vigentes a todos os seres e podem ser interpretados como princípios metafísicos que descrevem a estrutura mais geral da realidade.

Em seu aspecto metametafísico, por sua vez, nosso critério apresenta respostas a duas questões fundamentais. Ele tanto $(a)$ responde afirmativamente à questão da substancialidade e relevância da metafísica, quanto propõe que $(b)$ os métodos da lógica podem ser proveitosamente incluídos entre os métodos da investigação metafísica.

Quanto à questão $(a)$, se o que caracteriza um debate como genuinamente metafísico é a incompatibilidade lógica das posições adversárias, então todos os desacordos metafísicos são substanciais e fazem diferença. Afinal, se diferentes propostas metafísicas demandam lógicas diferentes, então nossos posicionamentos metafísicos, através de suas especificidades lógicas, influenciarão todos os demais assuntos sobre os quais raciocinamos. Os diferentes modos de fazer inferência que a divergência metafísica requer fazem com que esta divergência seja carregada para fora do limites da metafísica. Ela influenciará todos os assuntos, dos mais corriqueiros aos mais sofisticados. Então, se eventualmente nos deparamos na literatura com debates supostamente metafísicos, mas que não têm consequências que extrapolam seus próprios limites, isso só pode ter ocorrido quando as posições adversárias não são logicamente incompatíveis. Mas neste caso, segundo nosso critério, este não será um genuíno debate metafísico. Certamente a literatura está repleta de exemplos deste caso, e uma das principais motivações de nossa proposta é justamente separar estas discussões meramente verbais dos debates genuinamente metafísicos.

Nosso critério também responde à questão $(b)$, sobre os métodos da investigação metafísica, propiciando uma alternativa metodológica específica. E aqui é preciso ter bastante

${ }^{3}$ Um excelente exemplo desta tendência é Williamson (2015). 
cuidado. Por um lado, o critério é suficientemente atrevido para afirmar que qualquer proposta que mereça o rótulo de "metafísica" deve ter uma especificidade lógica, de modo que a toda proposta metafísica específica relaciona-se, como contrapartida, uma proposta lógica específica. Isso sem dúvida dá à lógica um papel metodológico privilegiado na investigação metafísica. Mas este papel privilegiado não deve ser confundido com exclusividade. De maneira nenhuma estou propondo o fim da metafísica e sua substituição pela lógica, nem tampouco pretendo legislar sobre os métodos legítimos nos quais a investigação metafísica deve ocorrer. As propostas metafísicas são produzidas e argumentadas pelos filósofos de diversas maneiras e em diversos estilos e tradições. E suas propostas e argumentações podem ser fortes e convincentes o suficiente para angariar adeptos, suplantar posições rivais e solucionar questões, sem que haja qualquer necessidade de apelo explícito à lógica. Esta saudável liberdade metodológica, no entanto, não impede ninguém de aplicar nosso critério para acessar, interpretar e fornecer a contrapartida lógica de uma proposta metafísica qualquer e, ao fazer isso, obter esclarecimento e compreensão suficientes para julgar, avaliar, decidir, completar e até apontar falhas na proposta original, nos termos em que ela foi originalmente produzida. Esta mesma liberdade metodológica também não impede ninguém de procurar na miríade atual de sistemas lógicos específicos, produzidos com as mais variadas motivações, que na maioria das vezes não têm a mais remota ligação com a metafísica, quais seriam as interpretações metafísicas específicas a eles vinculadas, retirando assim dos desenvolvimentos da lógica, argumentos e conteúdo metafísico.

Podemos, a título de ilustração, comparar a relação entre lógica e metafísica suscitada por nosso critério com o isomorfismo que Descartes mostrou haver entre álgebra e geometria, quando introduziu o sistema de coordenadas cartesianas, lançando as bases da geometria analítica. O surgimento da geometria analítica não destruiu nenhuma das duas disciplinas em que a matemática se dividia. Depois de Descartes, a álgebra continuou sendo álgebra e continuou sendo desenvolvida independentemente da geometria, tendo as mais variadas motivações e aplicações. Similarmente, a geometria continuou sendo geometria e continuou sendo desenvolvida independentemente da álgebra. No entanto, a geometria analítica possibilitou o uso da álgebra para a solução de problemas geométricos e o uso da geometria para a solução de problemas algébricos. A geometria analítica nos assegura que todo fato geométrico tem uma contraparte algébrica e vice-versa. Ela inclusive nos permitiu ampliar os horizontes da geometria para além das três dimensões de nossa intuição espacial, o que teve profundas e profícuas consequências em suas aplicações na física, por exemplo.

O critério que aqui defendo funda-se em uma hipótese que pode ser entendida, metaforicamente, como a admissão de um isomorfismo entre lógica e metafísica nos mesmos termos do isomorfismo entre álgebra e geometria que o sistema de coordenadas cartesianas nos dá. A lógica, então, seria para a metafísica o mesmo que a álgebra é para a geometria. O desenvolvimento da lógica é guiado pela pauta que os lógicos dão à sua disciplina, do mesmo modo que o desenvolvimento da álgebra é guiado pela pauta que os algebristas dão para a sua disciplina. Entre as muitas motivações e aplicações que pautam o trabalho dos algebristas hoje, há também as geométricas. Do mesmo modo, se a hipótese do isomorfismo entre lógica e metafísica for correta, então deveremos encontrar aplicações metafísicas nos desenvolvimentos já feitos em lógica, e poderemos incluir na pauta dos futuros desenvolvimentos em lógica também motivações e aplicações metafísicas. ${ }^{4}$

\footnotetext{
${ }^{4}$ No decorrer do texto usarei a expressão "critério da incompatibilidade lógica" para me referir ao critério de caracterização das divergências genuinamente metafísicas que intitula este artigo, e utilizarei
} 
Não estou de modo algum propondo o fim da metafísica e sua conversão em lógica. Nem tampouco estou propondo que todas as justificativas e motivações para as pesquisas em lógica sejam restritas à metafísica. Mas estou sim propondo que podemos olhar para as propostas metafísicas procurando suas contrapartidas lógicas, e que ao encontrá-las obteremos elementos que eventualmente podem melhorar nosso entendimento sobre estas propostas e podem nos ajudar a distinguir controvérsias genuinamente metafísicas de divergências meramente verbais ou de outra natureza. ${ }^{5}$

Dada a imensa amplitude e generalidade das propostas e disputas metafísicas e dos desenvolvimentos que hoje em dia são considerados fazer parte da lógica, estou ciente das enormes dificuldades que o critério que proponho enfrenta. Ainda não tenho respostas para a maioria delas. Também não espero angariar a simpatia dos metafísicos avessos a propostas fundadas em arregimentação formal, nem daqueles envolvidos em debates que segundo nosso critério não seriam classificados como genuinamente metafísicos. Aos primeiros, reforço que não proponho a substituição da metafísica pela lógica, mas apenas o uso de um critério lógico para a identificação da substancialidade dos debates metafísicos. Este critério, longe de substituir a metafísica e seus métodos, de atacá-la, reformá-la ou decretar seu fim, é, ao contrário, uma defesa de sua centralidade e importância. Ao vincularem-se a posicionamentos lógicos específicos, as proposições metafísicas garantem sua relevância e influência para fora de seus próprios limites, atingindo todos os demais assuntos sobre os quais raciocinamos. Aos segundos, aqueles filósofos envolvidos em debates que não seriam genuinamente metafísicos de acordo com nosso critério, acrescento que não ser classificado como metafísico não é, em geral, um demérito. Para a maioria das pessoas, na maioria das vezes, é exatamente o contrário disso, um mérito. O debate pode ser científico, religioso, cultural e, nestes casos, será quase sempre relevante. E ainda que o debate seja meramente verbal ou vocabular, pode ainda assim ter relevância ao esclarecer determinados usos e abusos das palavras. Talvez a própria tese que aqui defendo seja, no final das contas, ela mesma uma proposta meramente vocabular sobre o que deve ou não ser incluído sob o conceito de metafísica. Ainda que este seja o caso, a proposta não seria irrelevante e sem mérito apenas por isso.

Também estou ciente de que o critério que proponho envolve escolhas metodológicas e temáticas sobre como tratar cada uma das duas disciplinas, que certamente desagradarão a muitos. Lógicos e metafísicos poderão alegar que tanto a lógica quanto a metafísica são muito diversas ou mais amplas do que aquilo que estou incluindo sob a hipótese do isomorfismo. Meu único consolo sobre este ponto é negativo. As questões de delimitação são extremamente controversas e não há, que eu saiba, nenhuma proposta de delimitação destas duas disciplinas que tenha angariado adesão hegemônica. O que no momento acredito ter condições de oferecer é nada mais do que uma definição clara do critério, alguns esclarecimentos de seu significado, de seus compromissos e pressuposições filosóficas, juntamente com um conjunto de motivações tanto lógicas quanto metafísicas para a sua adoção, além de uns poucos exemplos de sua aplicação.

a expressão "hipótese do isomorfismo" para me referir a esta relação isomórfica entre lógica e metafísica que proponho como fundamento para o critério da incompatibilidade lógica.

${ }^{5}$ Uma outra consequência da admissão da hipótese do isomorfismo é que ela nos incita a fazer também a pesquisa inversa desta que ora nos ocupa. Ou seja, podemos olhar para as propostas lógicas procurando suas contrapartidas metafísicas e, se as encontrarmos, obteremos elementos que eventualmente podem melhorar nosso entendimento sobre estas propostas, ajudando-nos a esclarecê-las, justificá-las e classificálas. O critério oposto ao nosso título, nenhuma divergência lógica sem incompatibilidade metafísica, também merece nossa atenção e pesquisa. Mas isto é assunto para um outro artigo. 


\section{Metaontologia Quineana: compromisso ontológico}

Afirmar que o que caracteriza uma proposta como metafísica é a sua especificidade lógica, que não há divergência metafísica sem divergência lógica, evidencia um forte compromisso com a formalização e vincula nossa abordagem a uma tradição que teve na proposta metodológica de Quine para a ontologia seu modelo paradigmático. Mas o que é ontologia? Para a maioria dos filósofos a ontologia é uma subárea da metafísica. A metafísica lida com os aspectos da estrutura mais geral da realidade. Quais coisas ou tipos de coisas existem é um destes aspectos, e é o tema da ontologia. ${ }^{6}$ Nosso critério vincula-se à proposta metodológica de Quine e serve-se de muitos dos seus elementos. Os próximos passos serão, por isso, entender as linhas gerais da proposta de Quine, o que fazemos de modo bastante abreviado nesta sessão, e entender alguns de seus limites e problemas, o que fazemos na sessão seguinte. ${ }^{7}$

Aquilo que tomamos como verdadeiro nos compromete. Quine aproveitou esta platitude para propor uma metodologia naturalista para a ontologia. Ele introduziu um critério para identificar quais são os compromissos ontológicos das teorias que aceitamos e propôs que nossa ontologia deve conter exatamente as entidades que correspondem a estes compromissos ontológicos extraídos de nossas melhores teorias científicas.

Segundo Quine, ao assumirmos uma teoria como verdadeira, nos comprometemos com a existência de certas entidades que são os compromissos ontológicos da teoria:

Estamos condenados a uma pressuposição ontológica particular se, e somente se, o alegado pressuposto tiver que ser reconhecido entre as entidades sobre as quais variam nossas variáveis a fim de tornar uma de nossas afirmações verdadeiras. Quine (1963c, 13)

Ou seja, uma teoria compromete-se ontologicamente com espécies biológicas, por exemplo, quando a não inclusão de espécies biológicas entre as entidades que são valores das variáveis de suas sentenças faz com que algumas destas sentenças fiquem falsas.

Quine, seguindo a tradição inaugurada por Frege e Russell, vincula existência com quantificação. Esta vinculação faz com que estas entidades (que têm que estar entre os valores das variáveis das sentenças de nossas teorias para que elas sejam verdadeiras) sejam reveladas nas afirmações existenciais. Ele afirma explicitamente, "A existência é o que o quantificador existencial expressa. Há coisas do tipo $F$ se e somente se $\exists x F(x)$ " (Quine, 1969, 97). Então uma teoria compromete-se ontologicamente com espécies biológicas se a afirmação da existência de espécies biológicas estiver entre as sentenças da teoria. Em geral, uma teoria $\mathbf{T}$ compromete-se ontologicamente com entidades do tipo $P$ se e somente se a afirmação de que existem $P$ s está entre as afirmações da teoria. Em símbolos:

$$
\text { T compromete-se ontologicamente com } P_{\mathrm{s}} \Longleftrightarrow \mathrm{T} \vDash \exists \mathrm{x} \mathrm{P}(\mathrm{x})
$$

Outro fato importante à proposta de Quine, muitas vezes negligenciado, é que os portadores de compromissos ontológicos não são as sentenças tomadas isoladamente, mas teorias. E por teoria Quine entende sua definição lógica usual. Uma teoria é um conjunto de sentenças fechado pela relação de consequência lógica. Ou seja, dado um conjunto de sentenças T qualquer, a teoria T (da qual T é uma axiomática) conterá além das sentenças

${ }^{6}$ A distinção e delimitação entre ontologia e metafísica é também um assunto polêmico. Estou provisoriamente assumindo de modo acrítico a posição hegemônica entre os filósofos. A ontologia é uma subárea da metafísica que responde à questão sobre quais coisas existem. Nas próximas seções teremos mais a dizer sobre a distinção entre metafísica e ontologia.

7 Em Berto and Plebani (2015), van Inwagen (2009) e Durante (2014) há detalhadas e acessíveis exposições dos diversos elementos que compõem a proposta metodológica de Quine. 
de T todas as suas consequências lógicas. ${ }^{8}$ Então tratar um determinado discurso como uma teoria, ou seja, acrescentar ao discurso todas as suas consequências lógicas, nos dá a capacidade de identificar nas afirmações existenciais desta teoria todos os compromissos ontológicos do discurso.

Mas este é um critério lógico e formal. Nem a linguagem natural e nem mesmo as linguagens científicas semiformalizadas contém explicitamente variáveis e quantificadores existenciais. Então, antes de encontrar os compromissos ontológicos de uma teoria, é preciso arregimentá-la em uma notação canônica formal.

O método da ontologia, para Quine, requer assim três etapas:

(1) Arregimente as melhores teorias científicas em uma notação canônica formal.

(2) Use o critério definido acima para listar todos os compromissos ontológicos (dados pelas afirmações existenciais) destas teorias arregimentadas.

(3) Inclua em sua ontologia apenas as entidades correspondentes a estes compromissos ontológicos e nada mais.

A proposta de Quine para a ontologia é naturalista. A filosofia trabalha junto com a ciência. A ontologia, aliás, vem depois da ciência. Primeiro me dê as nossas melhores teorias científicas, depois te dou minha ontologia, dirá a filósofa (ou filósofo) engajada à proposta metodológica quineana.

Esta filósofa não tem qualquer liberdade sobre os passos 2 e 3. Eles são fixos. Correspondem a meras aplicações de procedimentos preestabelecidos. O espaço para o debate filosófico sobre ontologia ocorre, então, exclusivamente no passo 1 da estratégia, o passo da arregimentação através de paráfrases na notação canônica. Diferentes paráfrases podem levar a diferentes compromissos ontológicos. Mas como, segundo Quine, devemos sempre respeitar a navalha de Occam, então nossa ontologia deveria ser sempre aquela que se compromete com menos entidades. Incluiremos em nossa ontologia apenas aquelas entidades que forem indispensáveis.

Um debate ontológico sobre se determinado tipo de entidade $P$ existe, seria sempre um debate sobre a indispensabilidade $P$. Seja $T$ a teoria científica que lida com $P$ s. E sejam $\mathrm{T}_{1}, \ldots, \mathrm{T}_{\mathrm{n}}$ todas as arregimentações formais disponíveis de $T$. Se todas as arregimentações têm entre suas consequências lógicas a afirmação existencial $\exists x \mathrm{P}(\mathrm{x})$, ou seja, se para todo $(1 \leq \mathrm{i} \leq \mathrm{n}), \mathrm{T}_{\mathrm{i}} \vDash \exists \times \mathrm{P}(\mathrm{x})$, então as entidades $P$ são indispensáveis e devem entrar em nossa ontologia. Caso haja alguma arregimentação $T_{j},(1 \leq j \leq n)$ em que $\exists x P(x)$ não é uma de suas consequências lógicas, ou seja, caso haja algum $\mathrm{j}$ tal que $\mathrm{T}_{\mathrm{j}} \not \models \exists x \mathrm{P}(\mathrm{x})$, então as entidades do tipo $P$ não são indispensáveis e não devem entrar em nossa ontologia.

O debate ontológico resume-se, na metodologia quineana, às discussões dos filósofos sobre se diferentes propostas de arregimentação são ou não bem-sucedidas em parafrasear todo o conteúdo das teorias científicas. Dadas duas arregimentações bem-sucedidas neste quesito, ganha o debate ontológico aquela que assumir menos compromissos, a que for mais econômica ontologicamente.

Por exemplo, se for possível apresentar arregimentações formais de nossas melhores teorias científicas relacionadas com espécies biológicas que não possuam entre suas consequências lógicas a afirmação da existência de espécies biológicas, isto demonstrará que

${ }^{8}$ Em símbolos: $\mathbf{T}=\{\varphi / \mathrm{T} \vDash \varphi\}$. Uso a notação $\mathrm{T}$, grafada sem serifa, para denotar um conjunto qualquer de sentenças (um discurso), e a notação T, em negrito, para denotar o fecho dedutivo de $\mathrm{T}$. Ou seja, $\mathbf{T}$ denota a teoria completa da qual as sentenças de $\mathrm{T}$ são os axiomas. Deste modo a definição de compromisso ontológico apresentada acima também poderia ser dada por:

$$
\mathbf{T} \text { compromete-se ontologicamente com } P_{\mathrm{S}} \Longleftrightarrow \quad \exists \mathrm{x}(\mathrm{x}) \in \mathbf{T}
$$


a biologia não se compromete ontologicamente com espécies biológicas e elas não devem fazer parte de nossa ontologia, porque não são indispensáveis. Para Quine nossa ontologia deve conter apenas aquelas entidades que são indispensáveis às nossas melhores teorias científicas.

Já os números, por sua vez, Quine os incluía na ontologia, porque os via como indispensáveis. Muitas de nossas melhores teorias científicas comprometem-se ontologicamente com eles ao exigirem que números estejam entre os valores das variáveis quantificadas em suas afirmações existenciais. Os números deveriam, por isso, fazer parte da realidade e estar entre as coisas que existem.

Mas para que um debate ontológico deste tipo possa ser racionalmente conduzido, é preciso que seus participantes concordem previamente sobre algumas importantes questões fundamentais:

a) Os filósofos participantes do debate têm que concordar sobre quais são as nossas melhores teorias científicas, aquelas que merecem a consideração da filosofia.

b) Eles também têm que concordar sobre qual é a linguagem formal em que as arregimentações são feitas. Quais são os recursos formais que podem ser utilizados em nossas paráfrases arregimentadas?

c) Por fim, eles têm que concordar sobre qual é a lógica que governa todas as teorias. Afinal, lógicas diferentes apontarão diferentes sentenças entre as consequências de determinada teoria, o que pode levar a compromissos ontológicos diferentes.

As prescrições da metodologia quineana para estes acordos são bastante específicas e restritivas. Segundo ele, o item (a) é de responsabilidade dos cientistas não dos filósofos. $\mathrm{Na}$ ontologia naturalizada quineana não há espaço para a especulação filosófica a priori sobre o que existe. O trabalho dos filósofos começa apenas após o acordo científico sobre quais são as nossas melhores teorias.

Com relação ao item (b) Quine estipula que a arregimentação deve ser feita na linguagem da lógica de primeira ordem, com identidade, sem constantes individuais, tratando os nomes via teoria das descrições definidas de Russell. Esta linguagem formal na qual as arregimentações de todas as teorias científicas devem ser feitas para que seus compromissos ontológicos possam ser revelados ficou conhecida como a "notação canônica" de Quine. Finalmente, quanto ao item $(c)$, a única possibilidade legítima para Quine é a Lógica Clássica de Primeira Ordem, com o eventual complemento de sua teoria de conjuntos de primeira ordem NF. ${ }^{9}$

Esta proposta de Quine para a metodologia da ontologia tem muitos méritos. Sua noção geral de compromisso ontológico juntamente com os requerimentos da arregimentação formal e da indispensabilidade ajudaram a esclarecer inúmeras questões, tais como a suposta contradição das declarações de não-existência (Quine, 1963c). No entanto, suas prescrições para os acordos $(a),(b)$ e $(c)$ jamais ganharam adesão hegemônica.

No caso do acordo $(a)$, ainda que haja grande consenso em reconhecer que os compromissos ontológicos das teorias científicas devem ser seriamente considerados em qualquer proposta ontológica, muitos filósofos com inclinação menos naturalista não estão dispostos a aceitar que a ciência tenha exclusividade em ditar a pauta da ontologia. Mais graves do que esta divergência de postura são as limitações que as prescrições de Quine para os acordos $(b)$ e $(c)$ impõem à sua abordagem. Na próxima sessão explorarei uma destas limitações específicas e, ao final, proporei um modo de transpô-la que nos levará

${ }^{9}$ Ver Quine (1963b) e Durante (2011). 
diretamente ao esclarecimento do critério da incompatibilidade lógica e da hipótese do isomorfismo.

\section{Além da Ontologia: compromisso metafísico}

Suponha que estejamos interessados em investigar se os números existem independentemente de nosso pensamento ou se são constituídos exclusivamente por nossa atividade mental. Esta questão pode ser entendida de duas maneiras distintas, ou como uma pergunta ontológica mais restrita sobre se os números existem ou não, se fazem ou não parte da realidade; ou como uma pergunta metafísica mais ampla sobre qual o papel da mente na constituição da realidade matemática.

Por exemplo, algumas pessoas dirão que se os números são construções que só existem em nosso pensamento, então eles não fazem parte da realidade objetiva, na verdade não existem. Para estas pessoas, o pensamento está completamente separado da realidade e, portanto, o que está só no pensamento não existe na realidade. Para elas, então, a divergência sobre se os números são construções mentais ou são independentes de nosso pensamento não será uma questão metafísica ampla sobre a estrutura da realidade, mas uma questão ontológica restrita sobre se os números existem ou não. Se eles forem construções mentais, não existem. Se forem independentes de nosso pensamento, existem.

Entendida deste modo ontológico, a questão das entidades matemáticas é tratável pela metodologia de Quine, que nos ajudará a respondê-la em um de dois modos possíveis: ou os números existem, porque eles estão entre as afirmações existenciais das arregimentações de nossas melhores teorias científicas e são, por isso, indispensáveis; ou eles não existem, porque obtivemos sucesso na produção de arregimentações alternativas para as teorias científicas que não assumem compromissos ontológicos com os números. Quine admitiu a indispensabilidade dos números e os incluiu em sua ontologia. Mas para ele, tanto quanto a ciência, a ontologia e toda a filosofia também são revogáveis. Se algum dia conseguirmos produzir arregimentações alternativas e bem-sucedidas de nossas melhores teorias científicas que não assumam compromissos ontológicos com números, neste dia deveremos retirar os números de nossa ontologia. Alguns filósofos adotaram esta pauta e se lançaram nesta e em outras tarefas semelhantes com resultados parciais bastante interessantes. ${ }^{10}$

Mas seja qual for a resposta aqui, esta interpretação ontológica da questão fundamentase em um pressuposto mais geral sobre a estrutura da realidade: o que existe apenas em nossa mente, aquilo que é constituído apenas por nosso pensamento, não faz parte da realidade, não existe. Então a interpretação ontológica da questão compromete-se com a seguinte tese metafísica a respeito do papel da mente na estrutura geral da realidade, que poderíamos chamar de tese realista:

\section{(1) A mente está separada da realidade.}

A outra interpretação possível para a questão da relação dos números com o pensamento não a trata como uma questão ontológica restrita sobre a existência ou não dos números, mas como uma questão metafísica ampla sobre se a mente tem ou não papel na constituição da realidade matemática. Algumas pessoas podem não aceitar a tese realista (1) e por isso considerar que ser constituído por nossa mente faz parte dos traços admissíveis para a estrutura da realidade. Ou seja, para estas pessoas uma das características da realidade é que a mente pode ter papel constitutivo em pelo menos alguma parte sua, sustentando a existência de algumas das coisas que consideramos reais. Para elas, então, afirmar que

${ }^{10}$ Um ótimo exemplo de trabalhos deste tipo é Field (2016). 
os números são construções mentais não significa afirmar que eles não existem, significa ao invés afirmar que eles existem, e que a mente tem papel constitutivo em sua existência.

Mesmo que eu discorde desta posição e queira debatê-la, o debate que travarei não será ontológico. Não será um debate sobre se os números existem ou não, mas um debate metafísico sobre o papel da mente na estrutura da realidade. As duas respostas possíveis para esta interpretação da questão são: ou a nossa mente não tem papel algum na constituição da realidade matemática e os números, se existirem, existirão independentemente de nosso pensamento; ou nossa atividade mental tem papel constitutivo na realidade matemática e a existência dos números depende e é indissociável de nosso pensamento. A primeira resposta representa um compromisso com a tese realista (1), de que a mente está separada da realidade, pelo menos para o caso da realidade matemática, e a segunda resposta representa um compromisso com a tese oposta, que poderíamos chamar de tese idealista:

(2) A mente não está separada da realidade.

Posicionar-se com relação a este debate, no entanto, não nos compromete, necessariamente, com nenhuma tese ontológica sobre se os números existem ou não. Respondê-lo negando qualquer papel à mente na estrutura da realidade matemática deixa ainda sem resposta a questão sobre se os números existem ou não. Respondê-lo, ao contrário, atribuindo papel constitutivo à mente na estrutura da realidade matemática, aproxima-nos um pouco mais de um compromisso com a existência dos números. Mas não a tal ponto de tornar incoerente uma posição que assume a tese idealista (2) e ao mesmo tempo nega que o tipo de atividade mental relacionada com os números seja do tipo ontologicamente constitutivo. $^{11}$

Como não se trata de um debate ontológico, mas metafísico, sobre o papel da mente na estrutura da realidade, o método do compromisso ontológico de Quine não nos ajudará. Assumir ou evitar compromissos ontológicos com os números não nos vinculará a nenhum dos lados deste debate. Será que há algo que nos vincula? Haveria algo, algum padrão ou indicador que faria no caso de debates metafísicos como este o mesmo papel que os compromissos ontológicos fazem no caso de debates ontológicos? Haveria algo que pudéssemos chamar de compromisso metafísico de um discurso ou teoria? Nossa aposta é a de que há. Da mesma forma que as afirmações existenciais das teorias expressam seus compromissos ontológicos, o sistema de lógica que tomamos como regulando uma determinada teoria ou discurso expressaria seus compromissos metafísicos.

A ideia aqui é que se aceitamos o fundamento da noção de compromisso ontológico, ou seja, a concepção de que "a existência é o que o quantificador existencial expressa" (Quine, 1969, 97), então devemos aceitar também que os princípios lógicos que regulam o comportamento dos quantificadores e demais conectivos são princípios metafísicos que exprimem um conceito de existência e delimitam os aspectos estruturais mais básicos da realidade. Este fato é o principal fundamento de nossa hipótese do isomorfismo e do

${ }^{11} \mathrm{O}$ fundamento desta posição é o fato de que alguns de nossos pensamentos podem simplesmente não satisfazer os critérios que consideramos como suficientes para que eles sejam constitutivos do que tomamos como pertencente à realidade. Ainda que a mente crie realidade, isso não significa, necessariamente, que todos os nossos pensamentos casuais devam criar realidade. Pode ser que apenas os pensamentos que satisfaçam determinados critérios o façam. Com relação às entidades matemáticas esta seria uma posição bem estranha, já que não pensamos casualmente sobre elas, mas de um modo extremamente estruturado e regrado pela matemática. Poderíamos nos perguntar: se nem nossos pensamentos matemáticos satisfazem os critérios de constituir a realidade, quais pensamentos satisfariam? No entanto, apesar de estranha, esta não é uma posição logicamente impossível. 
critério da incompatibilidade lógica. Se as afirmações existenciais de uma teoria expressam as entidades com as quais esta teoria compromete-se ontologicamente, então a lógica que regula os aspectos mais gerais destas afirmações existenciais e todas as demais afirmações da teoria, a lógica que estabelece em que condições um conjunto de sentenças tem como consequência determinada afirmação (existencial ou universal ou de qualquer outro tipo) expressa os compromissos metafísicos desta teoria.

O próprio Quine não ignorava este fato. Em Existence and quantification, refletindo sobre as diferenças entre a lógica clássica e a intuicionista, ele, um tanto a contragosto, admite:

A teoria da quantificação clássica goza de uma extraordinária combinação de profundidade e simplicidade, beleza e utilidade. [...] Desvios dela, em contraste, tendem a parecer especialmente arbitrários. Mas como eles existem, o mais claro e simples é dizer que conceitos de existência desviantes existem junto com eles. (Quine, 1969, 112-113)

Neste mesmo texto, algumas páginas antes, Quine já havia afirmado que

[o] intuicionista tem uma doutrina do ser diferente da minha, na medida em que tem uma teoria da quantificação diferente; e eu simplesmente estou em desacordo com o intuicionista tanto num caso quanto no outro. (Quine, 1969, 108)

Quine admite explicitamente aqui que a diferença entre as teorias da quantificação clássica e intuicionista, ou seja, entre as lógicas de primeira ordem clássica e intuicionista constitui-se em uma diferença entre duas concepções distintas de existência, uma clássica e uma outra intuicionista. Assim a questão que talvez seja a mais central da metafísica, aquela que dá os traços mais gerais da estrutura da realidade ao abordar o significado e características da existência é simétrica à questão mais fundamental da lógica, sobre quais são os princípios lógicos universalmente válidos. Ao divergirem sobre quais são os princípios lógicos válidos, clássicos e intuicionistas divergem também, e por causa disso, nos modos como concebem a estrutura da realidade e entendem o próprio significado da existência.

Apesar deste reconhecimento, Quine simplesmente não estava disposto a debater metafísica nestes termos. Ele não estava interessado em testar as hipóteses metafísicas produzidas arbitrariamente e a priori pelos filósofos. Seu interesse no assunto limitava-se ao seu método ontológico naturalista descrito na seção anterior. A pauta da ontologia seria dada por nossas melhores teorias científicas que deveriam ser arregimentadas e avaliadas segundo a lógica clássica de primeira ordem. Então a doutrina metafísica de Quine, a única estrutura da realidade que ele se dispõe a aceitar é a que emana do (ou supervem ao) conceito de existência vinculado à lógica clássica de primeira ordem, que ele considerava adequado e suficiente para lidar com todas as questões ontológicas postas pelas teorias científicas. O método de Quine está limitado, então, ao que temos chamado de interpretação ontológica das questões metafísicas e a sua doutrina metafísica propriamente dita está limitada aos compromissos vinculados à lógica clássica de primeira ordem.

Mas qual exatamente é a doutrina metafísica vinculada ao conceito de existência dado pela lógica clássica de primeira ordem? Ao mesmo tempo que faz sentido afirmar que ao regularem o comportamento mais geral dos quantificadores os princípios lógicos constituem-se em princípios metafísicos, faz igual sentido perguntar qual é a imagem metafísica que estes princípios nos dão. Afinal, os metafísicos não costumam na maioria das vezes apresentar suas propostas através de princípios lógicos de inferência, mas através de proposições mais imagéticas como as teses realista (1) e idealista (2), por exemplo. 
Aqui a analogia com a geometria analítica proposta na Seção 2 novamente nos ajuda. Os princípios e teoremas lógicos seriam como as equações algébricas e a posição metafísica a eles vinculada seria como as figuras geométricas descritas pelas equações algébricas. À equação " $x^{2}+y^{2}=4$ ", por exemplo, vincula-se uma circunferência, de centro $(0,0)$ e raio 2. Podemos, analogamente, perguntar qual é a posição metafísica que se vincula aos teoremas e princípios da lógica clássica de primeira ordem. De um modo mais geral podemos nos perguntar como extrair as diferentes teses metafísicas dadas pelos conceitos de existência de diferentes sistemas lógicos.

Infelizmente não temos uma fórmula geral que responde a todas as questões deste tipo. A analogia com a geometria analítica chega aqui ao seu limite. Equações algébricas vinculam-se individualmente às figuras geométricas dadas por seus gráficos cartesianos. Mas não temos a pretensão de vincular um a um os princípios de inferência com suas supostas imagens metafísicas. Não creio que haja uma tal vinculação um-a-um. Da mesma forma que Quine defende que os portadores de compromissos ontológicos não são as sentenças tomadas individualmente, mas as teorias (conjuntos de sentenças fechados pela relação de consequência lógica), defendo igualmente que os portadores de compromissos metafísicos não são os princípios ou teoremas lógicos tomados individualmente, mas os sistemas lógicos. Lógicas distintas representariam conceitos de existência distintos e vinculariam-se a propostas metafísicas distintas sobre a estrutura da realidade.

A abordagem metodológica que sugiro, então, para esta tarefa de procurar quais são as posições metafísicas vinculadas aos diversos sistemas lógicos, consiste na análise lógica das propostas e debates metafísicos. O critério da incompatibilidade lógica propõe que uma divergência, um debate específico, será metafísico apenas quando as posições adversárias forem regidas por lógicas distintas. Devemos então vasculhar a literatura procurando pelos debates supostamente metafísicos e devemos fazer uma análise lógica das posições adversárias buscando identificar quais são os sistemas lógicos compatíveis com as inferências efetivamente empregadas em cada um dos lados de cada debate. Ao eventualmente encontrarmos um sistema lógico que seja compatível com a as inferências lógicas efetivamente utilizadas pelos defensores de uma proposta metafísica específica, poderemos vincular esta proposta metafísica explicitamente defendida ao sistema lógico compatível que encontramos. Ao fazer isso estaremos vinculando uma tese metafísica específica, defendida por um dos lados do debate, com um sistema lógico específico, o sistema compatível com as inferências lógicas efetivamente utilizas pelos defensores desta tese metafísica. Ao aplicarmos esta abordagem a inúmeros debates poderemos, pouco a pouco, compor a rede de posições metafísicas vinculadas aos diversos sistemas lógicos.

Esta abordagem metodológica, no entanto, precisa ser utilizada com bastante cautela. Na próxima Seção discutiremos um pouco mais detidamente as razões desta cautela. Utilizaremos a proposta de Michael Dummett para o tratamento das diversas instâncias do debate entre realismo $\mathrm{x}$ idealismo tanto como um exemplo de aplicação desta abordagem metodológica, quanto como um caso de aplicação bem sucedida do critério da incompatibilidade lógica.

\section{Realidade Diferente Demanda Lógica Diferente}

Conforme sugerimos na Seção anterior, ao limitar-se à interpretação ontológica das questões metafísicas, o método de Quine compromete-se com a posição metafísica dada pela tese realista (1) de que a mente está afastada da realidade. Mas além disso, vimos também 
que ao restringir-se à lógica clássica de primeira ordem, o método de Quine comprometese também com a posição metafísica vinculada ao conceito de existência expressado pela lógica clássica de primeira ordem. Juntando então estes dois compromissos poderíamos concluir que uma das características da posição metafísica vinculada à lógica clássica de primeira ordem é a tese realista (1).

Se este for mesmo o caso, em qualquer debate metafísico, qualquer um que restrinja a lógica que rege sua posição à lógica clássica de primeira ordem estará, em conjunto, assumindo a tese realista (1) que afirma que a mente está separada da realidade. Mais importante ainda, qualquer um que discorde da tese realista (1) e queira atacá-la, terá que abdicar da lógica clássica de primeira ordem e necessitará adotar uma lógica alternativa. Michael Dummett, que por motivos completamente diversos aos de Quine também defendia que lógicas diferentes se configuram em posições metafísicas diferentes (Durante, 2011), apontou que os matemáticos construtivistas da escola de Brower foram os primeiros a perceber que para rejeitar uma posição metafísica realista eles precisariam, também, rejeitar a lógica clássica (Dummett, 1991, 9).

O nosso critério da incompatibilidade lógica para os debates metafísicos fundamenta-se tanto no critério de compromisso ontológico de Quine, e em sua vinculação da existência com a quantificação, quanto nas propostas de Michael Dummett para uma teoria do significado, que nos daria "as bases lógicas da metafísica", título de seu livro seminal. Uma das principais preocupações metafísicas Dummett foi procurar uma metodologia unificada para o tratamento das diversas instâncias do debate entre as várias formas possíveis das teses realista (1) e idealista $(2) .{ }^{12}$

Dummett considerava equivocada a interpretação ontológica destes debates. Por exemplo, segundo ele um debate entre um fenomenalista e um realista com relação ao mundo físico não é um debate ontológico restrito sobre se os objetos materiais existem ou não, mas sim um debate metafísico amplo sobre qual é o papel da experiência sensorial na constituição da realidade física. Nosso conhecimento sobre o mundo físico é dado pelos sentidos, por nossas experiências sensíveis. Para os realistas estas experiências sensoriais não teriam qualquer papel na estrutura da realidade. Elas estariam completamente separadas da realidade sobre a qual nos informam e seriam veículos neutros de informação sobre o mundo físico. A versão da tese realista neste caso seria:

(1') A realidade está separada das experiências sensoriais.

Já para os fenomenalistas as nossas experiências sensoriais não seriam veículos neutros de informação sobre o mundo físico, mas teriam papel constitutivo na realidade física, fazendo parte de sua estrutura. O fenomenalismo é uma versão do idealismo, e a tese idealista específica que ele suporta seria:

12 Dummett preferia chamar de antirrealismo, ou de antirrealismos, as diversas teses que genericamente estou rotulando aqui de idealistas, das quais a tese (2) é apenas uma instância. Ele preferiu esta nomenclatura porque o termo idealismo é bastante carregado de interpretações vindas da história da filosofia com as quais ele queria evitar aproximações desnecessárias. Algumas das abordagens que ele classifica como antirrealistas, tais como o formalismo na filosofia da matemática, são, de fato, bastante distantes do significado tradicional de idealismo. Como ele considerava equivocada a abordagem tradicional às questões metafísicas e fez uma proposta metodológica reformista, ele preferiu utilizar uma nova terminologia. Optei, em contraste, por manter a terminologia tradicional justamente para ajudar a marcar o fato de que não tenho qualquer pretensão de que o critério da incompatibilidade lógica seja uma proposta metodológica reformista. Se bem-sucedido, o máximo que ele pode fornecer é um instrumento analítico para ajudar a interpretação e compreensão dos debates metafísicos, tanto os debates tradicionais quanto os contemporâneos. No contexto dos exemplos que utilizo aqui, os rótulos antirrealismo e idealismo podem, de um modo geral, ser entendidos como intercambiáveis sem maiores problemas. 


\section{(2') A realidade não está separada das experiências sensoriais.}

Da mesma forma, a divergência entre platonistas e construtivistas sobre as entidades matemáticas não é uma questão ontológica sobre se os números (e demais entidades matemáticas) existem ou não, mas uma divergência metafísica sobre o papel da mente na constituição da realidade matemática.

Dummett considerava equivocada a interpretação ontológica porque ele não via como estes debates, tratados como questões ontológicas, poderiam ser solucionados. Ele não partilhava da confiança de Quine no método naturalista fundado nos compromissos ontológicos das teorias científicas e nem tampouco aceitava as propostas ontológicas tradicionais e a priori dos filósofos, que ele chamava de abordagens de cima para baixo (top-down). Ele defendia, em contraste, uma abordagem de baixo para cima (bottom-up) que seria obtida através da proposição de uma teoria do significado para a parte da linguagem ligada aos termos do debate. Esta teoria do significado seria feita sem quaisquer pressuposições metafísicas iniciais, e seria baseada apenas no papel inferencial das expressões linguísticas que nos seria dado através de uma análise de seus usos. Ao entender, através de uma análise do uso da linguagem, o papel inferencial das expressões relacionadas a um dado posicionamento metafísico, entenderíamos o significado dos termos envolvidos, através da lógica (teoria do significado) que rege estes discursos. Deste entendimento emergiria de um modo apenas superveniente uma imagem metafísica da situação. A metafísica, para Dummett, se limitaria a esta imagem superveniente que emerge da lógica e da teoria do significado. ${ }^{13}$

Os debates deveriam ser tratados caso a caso e uma posição realista (ou idealista) com relação a determinada instância do debate não comprometeria ninguém com a mesma posição realista (ou idealista) nas demais instâncias. Apesar de defender a independência das diversas instâncias do debate, em sua busca por uma unificação metodológica Dummett identificou que o que liga todas as abordagens realistas por um lado e todas as abordagens contrárias ao realismo por outro é uma divergência no conceito de verdade.

Seja qual for a concepção de verdade e de realidade que adotemos, aquilo que tomamos como verdadeiro deve ser uma expressão da realidade (Chateaubriand, 2001, 16). Se além disso, de acordo com a tese realista, a realidade está separada da mente (ou da experiência sensorial), então aquilo que é verdadeiro também está. Ou seja, a verdade não pode depender de nossa mente nem de nossas experiências sensoriais. Assim, para um realista, uma afirmação será verdadeira ou falsa independentemente de nossas capacidades mentais ou sensoriais de verificar sua verdade ou falsidade. Dummett mostrou que a principal característica que une todas as abordagens realistas é que de acordo com elas a verdade é transcendente à verificabilidade.

Para os realistas, então, uma determinada afirmação declarativa $P$ deve ser verdadeira ou falsa, independentemente da possiblidade de haver ou não qualquer tipo de evidência contra ou a favor de P. O realismo, segundo esta concepção de Dummett, pode então ser entendido como uma defesa da neutralidade epistemológica da verdade. Para um realista a verdade ou falsidade de uma afirmação é independente de qualquer tipo de restrição que possa haver para o reconhecimento desta verdade ou falsidade.

Por outro lado, para um idealista (ou antirrealista na nomenclatura de Dummett), a mente ou a experiência sensorial não está separada da realidade, mas, ao contrário, faz parte de sua constituição e é indissociável dela. Então, sendo a verdade expressão da

${ }^{13}$ Uma boa apresentação desta proposta metodológica encontra-se na introdução de Dummett (1991), cujos demais capítulos a desenvolvem detalhadamente. 
realidade, aquilo que é verdadeiro também estará indissociavelmente ligado à nossa mente ou às nossas experiências sensoriais e, por isso, não pode haver verdade ou falsidade onde elas não podem ser mentalmente ou sensorialmente reconhecidas. Ou seja, para um antirrealista não há verdade ou falsidade onde não há condições de verificabilidade. Segundo Dummett, então, a principal característica que une todas as abordagens antirrealistas é que de acordo com elas a verdade depende da verificabilidade.

Uma sentença $P$, então, só pode ser verdadeira, para um antirrealista, mediante evidência favorável a $P$, e só pode ser falsa mediante evidência contrária a $P$. Então o antirrealismo representa, para Dummett, uma defesa da dependência epistemológica da verdade. Para um antirrealista a verdade e o reconhecimento da verdade não são noções distintas. São, ao contrário, indissociáveis. Não haverá verdade ou falsidade onde não pode haver reconhecimento da verdade ou falsidade.

Vejamos um rápido exemplo. Nós não sabemos com certeza se a afirmação "o universo é infinito" é verdadeira ou falsa. Há teorias divergentes sobre esta questão e não há evidências definitivas para assegurar nem sua verdade nem sua falsidade. Mais ainda, não sabemos se o tipo de evidência necessário para decidir a verdade ou falsidade desta afirmação poderá algum dia ser obtido. Ou seja, não há clareza sobre se é possível haver evidência para tal afirmação. Tomar estas incertezas sobre a verificabilidade da afirmação de que o universo é infinito como motivo suficiente para considerá-la nem verdadeira nem falsa é, segundo Dummett, adotar uma postura antirrealista com relação a questão da infinitude do universo. Por outro lado, admitir que a afirmação tem que ser verdadeira ou falsa independentemente da própria possibilidade de algum dia haver evidência favorável ou contrária a ela é, também segundo Dummett, adotar uma postura realista sobre esta questão.

Esta caracterização semântica de Dummett é compatível com nossa caracterização mais tradicionalmente metafísica ou imagética dos debates, representada pelas teses realista (1) e (1') e idealista (2) e (2'). Se aceitamos a tese realista e consideramos que a realidade do universo está separada de nossa mente ou sensibilidade, então ou ele é finito ou ele é infinito, independentemente de se há ou não possibilidade de algum dia obtermos evidência para o reconhecimento da verdade ou falsidade da afirmação de sua infinitude. Por outro lado, se aceitamos a tese idealista e consideramos que a realidade do universo depende de nossa mente ou sensibilidade, e se juntamente reconhecemos que a situação atual de nossas considerações científicas, filosóficas e empíricas sobre o universo não nos dá evidências suficientes para decidirmos sobre sua finitude ou infinitude, nem nos garante se algum dia poderá haver tais evidências, então devemos reconhecer também que a afirmação de que o universo é infinito não é nem verdadeira nem falsa, porque este ponto da realidade ainda não foi constituído por nossa sensibilidade ou pensamento, permanecendo um ponto aberto. Segundo a tese idealista não haveria, neste caso, qualquer fato na realidade sobre a infinitude ou finitude do universo e, portanto, também não haveria verdade ou falsidade vinculada à afirmação de que o universo é infinito.

Mas se para os realistas qualquer sentença declarativa $P$ deve ser verdadeira ou falsa, independentemente da evidência, então para qualquer $\mathrm{P}$ a declaração

$$
(\mathrm{P} \vee \neg \mathrm{P})
$$

que é o conhecido princípio lógico do terceiro excluído, será verdadeira. Afinal, quando P é verdadeira, $\neg P$ é falsa e quando $P$ é falsa, $\neg P$ é verdadeira, e a disjunção de verdadeiro com falso é sempre verdadeira. 
Por outro lado, se a verdade depende da verificabilidade, como os antirrealistas acreditam, então pode haver uma sentença $Q$ que careça de evidência tanto favorável quanto contrária. Neste caso, Q não é nem verdadeira nem falsa. Mas qualquer que seja o motivo para a falta de evidência da verdade ou falsidade de $Q$, ele será também um motivo para não haver evidência para a verdade ou falsidade de $\neg Q$, que também não será nem verdadeira nem falsa. Como tanto $Q$ quanto $\neg Q$ não são nem verdadeiras nem falsas, sua disjunção $(Q \vee \neg Q)$ também não será. Em particular, $(Q \vee \neg Q)$ não será verdadeira. $O u$ seja, nem todas as instâncias do terceiro excluído serão verdadeiras e, por isso, o terceiro excluído não será um princípio lógico para o antirrealista (Dummett, 1978) (Durante, 2011). ${ }^{14}$

Então apenas para os realistas o terceiro excluído será um princípio lógico, uma declaração impossível de ser falsa, verdadeira em todas as circunstâncias. Os antirrealistas não têm motivos para aceitar a validade irrestrita do terceiro excluído. Na verdade, eles têm motivos para rejeitá-la. A concepção mais geral da estrutura da realidade que eles assumem, na qual a mente ou a sensibilidade têm parte constitutiva e a verdade depende da verificabilidade, lhes dá motivos para negar a validade universal do terceiro excluído. Mas se realistas e antirrealistas discordam sobre a validade de um princípio lógico, então os sistemas lógicos que regulam as inferências aceitas por cada grupo são também diferentes. Ao rejeitarem o terceiro excluído, os antirrealistas rejeitam também todos os argumentos cuja validade depende do terceiro excluído e os dois grupos terão, por isso, padrões de inferência incompatíveis dados por lógicas diferentes e incompatíveis (Durante, 2011, 39).

É importante neste ponto deixar clara a distinção entre a abordagem de Dummett e a nossa proposta do critério da incompatibilidade lógica. Dummett queria reformar a metafísica. Para ele qualquer proposta metafísica descrita em linguagem tradicional, tal como as teses (1) e (2), seria apenas uma imagem superveniente de uma teoria do significado cujas bases lógicas constituiriam a única e verdadeira proposta metafísica. Ele não estava interessado em entender e elucidar os debates metafísicos tradicionais, mas em substituí-los por uma análise lógica e semântica. Neste sentido, para entender qualquer instância do debate realismo $\mathrm{x}$ antirrealismo, ele precisaria produzir uma teoria do significado completa para a parte da linguagem que contém os termos do debate. Esta mostrou-se uma exigência bastante forte, e um fardo pesadíssimo. Acredito que o motivo desta grande dificuldade em utilizar de modo completo o método de Dummett está no fato de que as nossas pressuposições metafísicas são quase sempre incompletas e pouco detalhadas, deixando abertos muitos pontos que seriam necessários para a produção de uma completa teoria do significado nos moldes de Dummett. Ao não serem totalmente definidas e possuírem aberturas, as nossas ideias sobre metafísica que influenciam nosso uso da linguagem ficam sujeitas a serem completadas de modo diferente por filósofos diferentes, o que geraria desacordos nas possíveis teorias do significado. Talvez esta dificuldade

14 Tanto no argumento realista para a aceitação do terceiro excluído, quanto neste argumento idealista para a sua rejeição, estou, obviamente, fazendo inferências lógicas. Alguém poderia, então, acusar a mim e a Michael Dummett de petição de princípio, afinal fazemos uso de princípios lógicos para justificar e criticar um princípio lógico. De um ponto de vista mais geral, não há saída para este dilema. Estamos condenados a fazer inferências lógicas em nossos argumentos, portanto, qualquer justificação de um princípio lógico será em algum sentido circular. No entanto, em nossa defesa neste caso específico, posso alegar que o próprio princípio lógico do terceiro excluído, cuja validade está sendo defendida por realistas e atacada por idealistas, não foi utilizado em nenhum dos dois argumentos. Utilizamos apenas princípios lógicos que poderíamos classificar de mais básicos, relacionados ao comportamento da negação e da disjunção em conexão com a presença e a ausência dos valores de verdade 'verdadeiro' e 'falso'. 
prática do método de Dummett explique porque sua abordagem, apesar de fecunda e interessante, tenha obtido tão poucos adeptos entre os filósofos contemporâneos.

Nossa proposta do critério da incompatibilidade lógica, no entanto, é bem menos pretensiosa. Nos exemplos de debates que temos apresentado, não descrevemos com detalhes as posições de cada um dos lados. Apenas mencionamos de um modo genérico os aspectos cruciais que esclarecem as divergências. No debate entre fenomenalismo e realismo sobre o mundo físico, por exemplo, o aspecto crucial é que um fenomenalista é alguém que defende a tese $\left(2^{\prime}\right)$ de que nossas experiências sensíveis fazem parte constitutiva da realidade física e um realista entende, ao contrário, que as experiências sensíveis estão separadas da realidade física, defendendo a tese (1'). O que interessa é apenas esta divergência crucial, sendo os detalhes das diversas maneiras possíveis de completar uma posição fenomenalista ou realista dispensáveis para o debate específico. Portanto, dada a incompletude e parcialidade destas descrições das posições de cada lado do debate, não temos a pretensão de definir qual é a lógica que representaria todos os compromissos metafísicos de fenomenalistas ou realistas com relação ao mundo físico. Eu não sei nem preciso saber quais são todos os compromissos metafísicos dos fenomenalistas e dos realistas para poder aplicar o critério da incompatibilidade lógica de modo bem-sucedido. A única coisa que eu preciso saber para reconhecer que este é um debate metafísico legítimo é que seja qual for a lógica que expressa todos os compromissos metafísicos de um dos lados do debate, esta lógica é diferente e incompatível com a lógica que expressa todos so compromissos metafísicos do outro lado. E isso nós sabemos. Vimos que o terceiro excluído é uma sentença logicamente válida para os realistas, mas apenas contingente para os fenomenalistas. Então, seja qual for a lógica que expressa todos os compromissos metafísicos dos realistas, ela é incompatível com a lógica que expressa todos os compromissos metafísicos dos fenomenalistas.

O único requisito necessário para aplicar de modo bem-sucedido o critério da incompatibilidade lógica a uma divergência específica é, então, que encontremos alguma característica lógica da posição de um dos lados que seja incompatível com a posição do outro lado. Para as diversas instâncias do debate entre realismo $x$ antirrealismo, Dummett nos mostrou que o princípio do terceiro excluído é uma destas características. As posições realistas aceitam o princípio do terceiro excluído, são compatíveis com ele. As posições antirrealistas, por seu turno, são incompatíveis com o terceiro excluído.

Devemos, no entanto, resistir à tentação de afirmar apressadamente que a lógica do realismo é a lógica clássica de primeira ordem e a lógica do idealismo é a lógica intuicionista. O que podemos afirmar com segurança é apenas que as teses idealistas são incompatíveis com a lógica clássica de primeira ordem e qualquer um que defenda uma posição idealista não pode aceitar a lógica clássica de primeira ordem como a lógica subjacente à sua posição. A lógica intuicionista de Heiting, alguma lógica intermediária (entre a intuicionista e a clássica), até mesmo a lógica modal S4 poderiam ser compatíveis com instâncias do idealismo. Analogamente, também podemos afirmar com segurança que as teses realistas são incompatíveis com a lógica intuicionista e com todas as lógicas compatíveis com a rejeição do terceiro excluído. Qualquer afirmação mais contundente neste sentido seria precipitada e desnecessária para uma aplicação bem-sucedida do critério da incompatibilidade lógica.

O exemplo mais bem desenvolvido destes debates entre realismo $\mathrm{x}$ antirrealismo é a divergência entre os matemáticos platonistas e construtivistas sobre o papel da mente na constituição da realidade matemática, que abordamos na Seção 4. Neste exemplo específico temos de um modo mais contundente a vinculação da lógica clássica de primeira ordem como a lógica que expressa todos os compromissos metafísicos da posição realista assumida 
pelos matemáticos platonistas e a vinculação da lógica intuicionista como representando os compromissos metafísicos dos construtivistas. Este estado mais bem desenvolvido da explicitação das lógicas que representam os compromissos metafísicos de cada lado deste debate específico deve-se às características especiais da matemática, que tornam bastante explícitas as inferências lógicas empregadas em seu desenvolvimento. Mas mesmo aqui há margem para múltiplas interpretações. Não há acordo sobre qual versão da lógica intuicionista é a mais adequada para exprimir os compromissos metafísicos dos construtivistas, se a lógica intuicionista de Heyting, ou a lógica intuicionista minimal, um pouco mais restritiva, ou mesmo a lógica positiva ou outras versões mais restritivas ainda. De todo modo, na grande maioria dos debates metafísicos, as posições de cada lado não são tão detalhadas e precisas, e o máximo que podemos almejar é a identificação de alguma incompatibilidade lógica entre as posições adversárias que nos daria uma garantia de que as posições representadas por cada lado são, de fato, metafisicamente divergentes.

Exemplificamos, nesta Seção, um caso de aplicação bem-sucedida do critério da incompatibilidade lógica, e analisamos com algum detalhe quais os requisitos para uma tal aplicação e que informações ela nos dá. Vimos, através dos argumentos semânticos de Dummett sobre a divergência no conceito de verdade, que as diversas instâncias do debate entre realismo e antirrealismo, quando não são interpretadas de um modo ontológico restrito, configuram-se em genuínos debates metafísicos, porque as posições adversárias são logicamente incompatíveis. O lado realista aceita o terceiro excluído como uma validade lógica e o lado antirrealista o rejeita, tratando-o como uma sentença contingente que pode ser falsa em algumas circunstâncias. Na próxima Seção vamos criticar a tese tradicional de que haveria uma separação fundamental entre lógica e metafísica. De acordo com esta tese haveria uma separação entre os aspectos formais e materiais da realidade; a lógica seria responsável apenas pelos primeiros ao passo que a metafísica cuidaria exclusivamente dos segundos.

\section{O Formal Encontra o Material: princípios lógicos como princípios metafísicos}

O paradoxo do barbeiro é bastante conhecido e pode ser assim expresso: imagine uma pequena vila na qual mora e trabalha apenas um barbeiro que faz a barba de todos e apenas os habitantes que têm barba e não fazem a própria barba. Esta singela situação é paradoxal porque podemos fazer a seguinte pergunta capciosa: este barbeiro faz a própria barba? Se supusermos que ele faz, concluiremos que ele não faz, porque ao fazer a própria barba ele não satisfaz a condição que descreve quem são os habitantes que ele barbeia. Dissemos que ele barbeia apenas os que não fazem a própria barba. Por outro lado, se supusermos que ele não faz a própria barba, concluiremos que ele faz, porque ao não fazer a própria barba ele satisfaz a condição que descreve quem são os habitantes que ele barbeia. Dissemos que ele barbeia todos os que não fazem a própria barba. Temos, portanto, um paradoxo, porque qualquer tentativa de atribuirmos verdade ou falsidade à afirmação "o barbeiro faz a própria barba" falha, pois, conforme expusemos, a suposição de verdade desta afirmação implica na sua falsidade e a suposição de falsidade implica na sua verdade.

Nathan Salmon ${ }^{15}$ apresentou uma solução bastante interessante para o paradoxo do barbeiro. Ele disse que não há paradoxo do barbeiro porque um teorema lógico, que ele

${ }^{15}$ Em uma conferência proferida no IX Congresso Internacional de Filosofia Analítica, ocorrido em Fortaleza, em maio de 2014. 
chamou de lei de Russell, garante que não pode existir nenhum barbeiro que faz a barba de todos e apenas os que não se barbeiam.

A lei de Russell é um teorema da lógica clássica de primeira ordem, ou seja, é um princípio lógico, uma declaração verdadeira em qualquer interpretação. Ela afirma que não há indivíduo x nem relação $R$ em que $x$ relaciona-se através de $R$ com todos e apenas os indivíduos y que não se relacionam consigo mesmos através de R. Em linguagem formal:

$$
\neg \exists x \forall y(R(x, y) \leftrightarrow \neg R(y, y))
$$

Considere agora a seguinte relação binária interpretada:

FazABarba(x,y): x faz a barba de y.

Se a lei de Russell é verdadeira para uma relação $R$ qualquer, ela é em particular verdadeira para a relação FazABarba. Então a seguinte sentença, instância obtida da lei de Russell substituindo-se a relação genérica $R$ pela relação específica e interpretada FazABarba, também é um teorema da lógica clássica de primeira ordem:

$$
\neg \exists \mathrm{x} \forall \mathrm{y}(\mathrm{FazABarba}(\mathrm{x}, \mathrm{y}) \leftrightarrow \neg \mathrm{FazABarba}(\mathrm{y}, \mathrm{y}))
$$

Mas esta sentença afirma precisamente que não há indivíduo que faz a barba de todos e apenas os indivíduos que não fazem a própria barba. Ou seja, a declaração de que não existe um barbeiro que faz a barba de todos e apenas os indivíduos que não se barbeiam é uma verdade lógica; um teorema da lógica clássica de primeira ordem que não pode ser falso. Então, afirma Salmon, as leis da lógica proíbem a existência do barbeiro do paradoxo. É logicamente impossível que haja um barbeiro que faça a barba de todos e apenas os que não se barbeiam, porque a declaração de sua não existência é um teorema lógico, uma sentença verdadeira em todas as circunstâncias possíveis. Não havendo tal barbeiro, não há também qualquer paradoxo que, pelos poderes da lógica clássica de primeira ordem, está solucionado.

Esta engenhosa solução do paradoxo do barbeiro proposta por Salmon assume dois compromissos indissociáveis:

( $i$ ) Ela assume que seja qual for a lógica que rege nossas inferências sobre cidades, barbeiros e demais fatos corriqueiros da vida, esta lógica é compatível com a lógica clássica de primeira ordem, no sentido de que os teoremas da lógica clássica de primeira ordem também serão teoremas desta lógica.

(ii) Ela também assume que aquilo cuja existência é proibida pela lógica clássica de primeira ordem, tal como o nosso barbeiro paradoxal, de fato não existe. $\mathrm{Ou}$ seja, aquilo cuja negação de sua existência é um teorema da lógica clássica de primeira ordem não existe mesmo.

O compromisso $(i)$ é um compromisso com a lógica clássica de primeira ordem e o compromisso (ii) é um compromisso com o conceito de existência vinculado à lógica clássica de primeira ordem. Ao justificar a não existência do barbeiro afirmando que ela se segue de um teorema lógico, Salmon está utilizando este teorema como um princípio metafísico, que explicita uma característica fundamental de todos os seres. A saber: não há, não pode haver indivíduo que se relacione com todos e apenas os indivíduos que não se relacionam consigo mesmos. Esta é uma característica de todos os indivíduos e de todas as relações. É, por isso, um princípio metafísico. ${ }^{16}$

16 O paradoxo do barbeiro é apenas uma versão lúdico-didática do paradoxo de Russell, que levou os matemáticos a abandonarem o esquema da compreensão irrestrita, $\exists \mathrm{x} \forall \mathrm{y}((\mathrm{y} \in \mathrm{x}) \leftrightarrow \varphi(\mathrm{y}))$, juntamente com toda a teoria de conjuntos ingênua. Se instanciamos ' $\varphi(y)$ ' por ' $\neg(\mathrm{y} \in \mathrm{y})$ ', obtemos $\exists x \forall y((y \in x) \leftrightarrow \neg(y \in y))$, cuja negação é uma instância da lei de Russell com ' $\in$ ' no lugar de 'R'. Então nem todas as propriedades significativas exprimíveis em linguagem de primeira ordem definem um 
De modo análogo, podemos considerar que todos os teoremas lógicos universais, com a forma

$$
\forall \mathbf{x} \alpha(\mathbf{x})
$$

representam necessidades ou obrigações impostas a todos os seres, e os teoremas com a forma de negações de sentenças existenciais

$$
\neg \exists \mathrm{x} \alpha(\mathbf{x})
$$

representam, como a lei de Russell, impossibilidades ou proibições a eles impostas. O conjunto dos teoremas com estas formas de uma dada lógica $\mathbf{L}$ caracteriza de modo bastante explícito o comportamento mais geral dos seres segundo esta lógica e, ao fazer isso, configura-se em uma detalhada explicitação metafísica da estrutura da realidade e do conceito de existência vinculados à lógica $\mathbf{L}$.

Por exemplo, o teorema clássico

$$
\neg \exists \mathrm{x}(\mathrm{P}(\mathrm{x}) \wedge \neg \mathrm{P}(\mathrm{x}))
$$

estabelece uma característica de todos os seres admissíveis por quem raciocina segundo a lógica clássica, que se constitui na proibição ou impossibilidade de qualquer indivíduo satisfazer e não satisfazer uma propriedade $\mathrm{P}$ qualquer. Já o teorema clássico

$$
\forall \mathrm{y}(\mathrm{P}(\mathrm{y}) \vee \neg \mathrm{P}(\mathrm{y}))
$$

estabelece uma característica de todos os seres admissíveis sob a razão clássica que se constitui na obrigação ou necessidade de qualquer indivíduo satisfazer ou não satisfazer uma propriedade $\mathrm{P}$ qualquer.

Ao descreverem o que é impossível (ou proibido) e o que é necessário (ou obrigatório) a todos os seres, sem exceção, estes e os demais teoremas quantificacionais da lógica clássica constituem-se em uma caracterização da estrutura mais geral imposta a todos os seres, o que faz da lógica clássica uma doutrina metafísica.

Apresentada nestes termos lógicos, no entanto, esta doutrina metafísica carece dos apelos imagéticos das proposições metafísicas tradicionais. Os teoremas quantificacionais de um sistema lógico são como as equações algébricas que descrevem analiticamente uma situação geométrica cuja imagem superveniente só nos é dada à intuição pelas figuras obtidas nos gráficos cartesianos destas equações. As proposições metafísicas tradicionais corresponderiam às figuras geométricas dadas por estas imagens dos gráficos cartesianos. Mas do mesmo modo que o isomorfismo cartesiano mostrou que as equações algébricas e as figuras geométricas são apenas dois modos diferentes de apresentar e entender os mesmos fatos, a nossa hipótese do isomorfismo assume que as doutrinas metafísicas vinculadas aos sistemas lógicos são apenas um modo diferente, analítico, de apresentar teses metafísicas que, tradicionalmente, são apresentadas e discutidas do modo mais geométrico e intuitivo preferido pelos metafísicos.

Por um lado, as nossas práticas inferenciais tais como a exemplificada na solução de Nathan Salmon ao paradoxo do barbeiro corroboram o peso metafísico que damos aos teoremas quantificacionais da lógica. Mas por outro lado, os filósofos não costumam reconhecer ou rotular de metafísica a estrutura da realidade que os teoremas quantificacionais da lógica nos obrigam a aceitar. Eles, em geral, a rotulam de estrutura formal e tendem

conjunto. A lei de Russell impede que a propriedade "não é um membro de si mesmo", que além de significativa é exprimível por ' $\neg(\mathrm{y} \in \mathrm{y})$ ', exista enquanto uma individualidade dada pelo conjunto de sua extensão. Esta restrição significa que propriedades não podem ser indiscriminadamente tratadas como coisas individuais que existem. A lei de Russell nos mostra que este fato não é uma limitação da teoria de conjuntos, mas uma característica da estrutura realidade dada pela lógica clássica, ou seja, um compromisso metafísico de todos os que raciocinam de acordo com a lógica clássica de primeira ordem. 
a separar o domínio formal da lógica do domínio material da metafísica que seria o único ligado ao ser.

Esta separação pode ser explicada por dois fatores. O primeiro é a ubiquidade que a tese da neutralidade metafísica da lógica atingiu na ortodoxia contemporânea. E o segundo fator, relacionado ao primeiro, é que ao vasculharmos a história da filosofia veremos que a concepção dominante sempre foi a de que há uma única lógica, que se aprimorou ao longo do tempo, mas manteve-se até bem recentemente a única lógica. Já as propostas metafísicas sempre foram múltiplas e motivo de controvérsias desde a antiguidade. Havendo apenas uma lógica e muitas propostas metafísicas, não faria muito sentido rotular de metafísicas as exigências que esta lógica única impõe à estrutura da realidade. A lógica foi, então, tradicionalmente, vista como anterior à metafísica, neutra com relação às diversas controvérsias desta disciplina. E as exigências que a lógica faz à estrutura da realidade foram rotuladas de formais, em contraste com as exigências da metafísica que seriam materiais ou substanciais. Porém, a proliferação de propostas de sistemas lógicos alternativos ocorrida a partir da segunda metade do século XX deu-nos a oportunidade teórica de refletir sobre a natureza das diferentes exigências à estrutura da realidade feitas por diferentes sistemas lógicos e desafiar a sua classificação como exigências meramente formais. É isso que estamos fazendo neste artigo.

Podemos, por exemplo, refletir sobre o fato de que uma das exigências que a lógica clássica de primeira ordem faz à estrutura da realidade e que não é feita pela lógica intuicionista é que, segundo a lógica clássica, tudo o que existe deve satisfazer a seguinte obrigação:

$$
\forall \mathrm{y}(\mathrm{P}(\mathrm{y}) \vee \neg \mathrm{P}(\mathrm{y}))
$$

A estrutura da realidade vinculada à lógica clássica é mais rígida do que aquela vinculada à lógica intuicionista, porque a primeira faz mais exigências do que a segunda. Todos os teoremas intuicionistas são teoremas clássicos, mas não o oposto. A fórmula acima, uma variação em primeira ordem do terceiro excluído, é teorema clássico, mas não é teorema intuicionista. Muitas outras fórmulas são teoremas clássicos, mas não intuicionistas. Então o conceito de existência dado pela lógica clássica exige de cada coisa que existe que ela satisfaça ou não satisfaça uma propriedade qualquer P. Já o conceito de existência dado pela lógica intuicionista não faz esta exigência. A estrutura da realidade da lógica intuicionista admite seres para os quais há certas propriedades que eles nem a satisfazem nem não a satisfazem. Então, a realidade da lógica intuicionista tem mais possibilidades que a realidade da lógica clássica. Sua estrutura é menos rígida, porque ela tem menos regras que a realidade descrita pela lógica clássica. Há fatos admissíveis aos seres concebidos segundo a lógica intuicionista que são inadmissíveis aos seres quando estes são concebidos segundo a lógica clássica. Se lembrarmos de nossas discussões da Seção anterior que relacionam o terceiro excluído às teses realistas e a rejeição do terceiro excluído às teses idealistas, esta estrutura menos rígida ligada à lógica intuicionista faz todo o sentido. Se a mente ou nossa sensibilidade tem papel constitutivo na realidade, conforme defendem os idealistas, então a realidade é mais maleável do que se ela fosse completamente independente de nossas capacidades. Se a mente, por exemplo, tem função constitutiva na realidade, podemos imaginar os seres como estando sujeitos a transformações ou processos possibilitados por nossa atividade mental que seriam proibidos aos seres quando sua existência é concebida como independente de nossa mente. A nossa mente poderia produzir fatos reais que seriam impossíveis ou inconcebíveis quando desvinculamos a existência de nossa atividade mental, como fazem os realistas. 
Estas considerações sugerem que não há qualquer motivo a priori para separarmos as características estruturais da realidade dadas pelos teoremas lógicos, tais como $\forall \mathrm{y}(\mathrm{P}(\mathrm{y}) \vee \neg \mathrm{P}(\mathrm{y}))$, como sendo de uma natureza formal e diversa das características estruturais da realidade dadas por princípios que temos historicamente chamados de metafísicos, como as teses realista e idealista. Os que defendem esta separação costumam apelar para as noções de possibilidade e necessidade. Dizem que há possibilidades lógicas que não são metafisicamente possíveis e que há necessidades metafísicas que não são logicamente necessárias.

Por exemplo, alguém poderia argumentar que seria logicamente possível, mas não metafisicamente possível, existir um indivíduo com o poder mágico de transformar qualquer objeto material em qualquer outro instantaneamente e sem esforço. Dizer que a existência deste indivíduo é logicamente possível significa dizer que a admissão de sua existência não implica nenhuma contradição lógica. Ao passo que dizer que a existência deste indivíduo não é metafisicamente possível significa dizer que a suposição de sua existência, apesar de não implicar nenhuma contradição lógica, contraria algum princípio que tomamos como princípio metafísico.

Porém, esta separação entre a natureza do que é lógico e do que é metafísico é arbitrária. Ela parte da pressuposição de que a lógica é anterior e mais ampla do que a metafísica. Mas não encontramos qualquer justificativa mais sólida para esta pressuposição além das frágeis razões históricas anteriormente mencionadas, relacionadas com a concepção largamente assumida no passado de que haveria apenas uma lógica mas muitas propostas metafísicas. Há, ao contrário, um motivo bastante razoável para negarmos esta separação e apostarmos na hipótese do isomorfismo entre lógica e metafísica. Ele se constitui no fato de que a principal característica tanto dos princípios tradicionalmente tidos como metafísicos quanto dos princípios lógicos, normalmente caracterizados como formais, é que estes dois tipos de princípios são absolutamente gerais. O aspecto mais básico que caracterizaria tanto a lógica quanto a metafísica seria a generalidade absoluta dos princípios destas duas disciplinas.

Na próxima Seção vamos argumentar em defesa desta tese da generalidade absoluta da lógica e, ao fazer isso, apresentaremos algumas motivações lógicas para a hipótese (do isomorfismo) de que os princípios lógicos se constituem em princípios metafísicos.

\section{A Lógica Não Separa: generalidade absoluta}

A definição tradicional da metafísica como a disciplina que lida com a caracterização da estrutura mais geral da realidade evidencia a sua generalidade absoluta. A estrutura mais geral da realidade é aquela da qual nada escapa. Porém, o que significa dizer que os princípios da lógica têm generalidade absoluta? Quando afirmo que os princípios da lógica têm generalidade absoluta, quero dizer com isso que os teoremas quantificacionais da lógica não dividem nem separam a realidade. Eles não se referem a seres específicos ou a parte dos seres. Eles sempre se referem a todos os seres. Quero dizer que não é possível afirmar nada particular através de um teorema quantificacional, mas apenas fazer afirmações absolutamente gerais que, justamente por isso, caracterizam a estrutura mais geral da realidade, configurando-se em princípios metafísicos. ${ }^{17}$

\footnotetext{
17 A expressão "generalidade absoluta" costuma ser empregada na literatura relacionada ao domínio dos quantificadores e tem, neste contexto, um sentido diverso ao que uso aqui. Os detratores da tese da generalidade absoluta do domínio de quantificação assumem a posição de que é incoerente admitir que possa haver um domínio de quantificação absolutamente geral, que inclui absolutamente tudo, sem nenhuma restrição. Os domínios de todas as sentenças quantificacionais seriam sempre relativos a alguma
} 
Não estou aqui me referindo a uma característica da lógica clássica ou de algum sistema lógico específico, mas a uma característica que considero fundamental a qualquer sistema lógico. Tão fundamental que serviria como um dos critérios necessários para a caracterização do que é lógica. Não pode haver, por isso, um teorema com demonstração que assegure a generalidade absoluta de qualquer sistema lógico. Podemos até enunciar e demonstrar um teorema similar, mas ele sempre será específico para algum sistema ou conjunto de sistemas lógicos particulares. Trata-se de uma questão de delimitação disciplinar e muitos lógicos poderão discordar desta proposta. O melhor que podemos fazer é apresentar argumentos e motivações para a aceitação deste critério, esperando que não estejamos sendo neste quesito tão arbitrários quanto aqueles que acusamos de arbitrariamente classificar a lógica como anterior e neutra com relação à metafísica.

Para além dos argumentos já apresentados nas Seções anteriores que nos encaminharam à proposição da generalidade absoluta da lógica, vou reforçar a motivação para a sua adoção argumentando que a lógica de primeira ordem clássica, tanto quanto a intuicionista, satisfazem a generalidade absoluta. Dissemos acima que todos os teoremas lógicos com as formas

$$
\forall \mathrm{x} \alpha(\mathrm{x}) \quad \text { e } \neg \exists \mathrm{x} \alpha(\mathrm{x})
$$

são princípios metafísicos que estabelecem obrigações e proibições que caracterizam o comportamento mais geral dos seres. Mas e quanto aos demais teoremas lógicos, tais como os teoremas proposicionais? Qual sua relação com a metafísica?

Os teoremas de um sistema lógico relacionam-se uns com os outros, de modo que dado um teorema proposicional qualquer, sempre é possível encontrar versões quantificacionais dele que também serão teoremas. Os teoremas quantificacionais clássicos

$$
\forall \mathrm{y}(\mathrm{Q}(\mathrm{y}) \vee \neg \mathrm{Q}(\mathrm{y})) \quad \text { e } \quad \neg \exists \mathrm{x}(\mathrm{P}(\mathrm{x}) \wedge \neg \mathrm{P}(\mathrm{x}))
$$

que apresentamos anteriormente são versões quantificacionais dos teoremas proposicionais clássicos

$$
(\mathrm{Q} \vee \neg \mathrm{Q}) \quad \text { e } \quad \neg(\mathrm{P} \wedge \neg \mathrm{P}) .
$$

Este relacionamento entre os teoremas dos sistemas lógicos faz com que divergências nos teoremas proposicionais tenham consequências nos teoremas quantificacionais. A diferença entre a lógica clássica e a intuicionista é proposicional. Mas esta diferença proposicional tem consequências nos teoremas quantificacionais. Exatamente porque o terceiro excluído $(\mathrm{Q} \vee \neg \mathrm{Q})$ não é teorema da lógica intuicionista, esta sua versão quantificacional $\forall \mathrm{y}(\mathrm{Q}(\mathrm{y}) \vee \neg \mathrm{Q}(\mathrm{y}))$ também não será.

É justamente porque as divergências proposicionais têm consequências quantificacionais, que não precisamos limitar o critério da incompatibilidade lógica aos teoremas

classe restritiva. Já os defensores da tese da generalidade absoluta assumem que não há qualquer problema na admissão de um domínio de quantificação absolutamente genérico, que inclui absolutamente tudo (Santos, 2013). Meu uso da expressão "generalidade absoluta" neste texto não tem relação com este debate. Quando afirmo que uma determinada sentença quantificacional T é absolutamente geral (ou genérica), quero dizer com isso que para qualquer domínio de quantificação $\mathbf{D}$, aquilo que $\mathbf{T}$ afirma aplica-se a todos os indivíduos do domínio $\mathbf{D}$ e não a apenas alguns. Então, se $\mathbf{T}$ é uma sentença absolutamente genérica, dado qualquer domínio de quantificação $\mathbf{D}, \mathbf{T}$ não separa os elementos de $\mathbf{D}$ entre os que a satisfazem e os que não a satisfazem. Ela é absolutamente geral porque é satisfeita por todos. O exemplo típico de uma afirmação absolutamente genérica é uma afirmação universal $\forall x \alpha(\mathrm{x})$. Mas há afirmações absolutamente gerais com outras formas lógicas, por isso a necessidade de um nome específico. Quando afirmo que um sistema lógico satisfaz a generalidade absoluta, quero dizer algo muito próximo da afirmação de que todos os seus teoremas quantificacionais são afirmações absolutamente genéricas, com alguns adendos que serão esclarecidos ao longo desta Seção. 
quantificacionais. Para que uma lógica forneça um conceito de existência, é preciso que ela tenha quantificadores e seja pelo menos de primeira ordem. No entanto, como divergências proposicionais têm consequências quantificacionais, qualquer divergência lógica, mesmo que no nível proposicional, conecta-se a divergências quantificacionais e por isso caracteriza uma divergência metafísica. É também por causa desta interconexão entre os teoremas lógicos que afirmamos anteriormente que são os sistemas lógicos entendidos em sua totalidade e não os princípios lógicos isolados que expressam compromissos metafísicos.

Uma maneira bastante direta de demonstrar que um determinado sistema lógico $\mathbf{L}$ satisfaz o critério da generalidade absoluta seria demonstrar que $\mathbf{L}$ não tem afirmações existenciais entre seus teoremas. Ou seja, a generalidade absoluta de $\mathbf{L}$ estaria assegurada se nenhum de seus teoremas tivesse a forma $\exists \mathrm{x} \alpha(\mathrm{x})$. Isso porque as sentenças existenciais são exatamente aquelas que dividem a realidade, que afirmam particularidades, especificidades de alguns seres, mas não de todos. Quando afirmo, por exemplo, que fantasmas

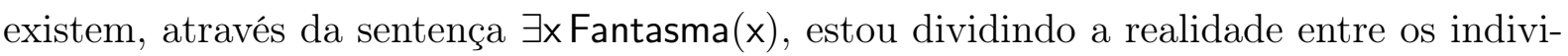
duos que a satisfazem e os que não a satisfazem, estou afirmando uma particularidade, destacando um aspecto específico da realidade e não uma característica geral. Ao afirmarem particularidades e especificidades aplicáveis apenas a alguns indivíduos, as afirmações existenciais não descreveriam as características mais gerais de todos os seres, não seriam absolutamente gerais. Então, se defendo que uma característica fundamental de qualquer princípio lógico é a sua generalidade absoluta, nenhum princípio lógico deveria ter a forma $\exists \mathrm{x} \alpha(\mathrm{x})$ e, portanto, nenhum sistema lógico deveria ter afirmações existenciais entre os seus teoremas. ${ }^{18} \mathrm{O}$ problema é que esta é uma suposição falsa.

A afirmaçao existencial $\exists x(P(x) \vee \neg P(x))$, por exemplo, é um teorema da lógica clássica de primeira ordem. Em geral, se $\alpha$ é um teorema proposicional, então $\exists x \alpha(\mathrm{x})$ também é teorema e, por isso, a lógica clássica está repleta de afirmações existenciais entre seus teoremas. Há, no entanto, uma esperança para esta situação. Quando $\alpha$ é um teorema proposicional, não só $\exists \mathbf{x} \alpha(\mathbf{x})$ mas também $\forall \mathbf{x} \alpha(\mathbf{x})$ é teorema quantificacional. Ou seja:

$$
\vdash \alpha \Rightarrow \vdash \exists \mathrm{x} \alpha(\mathrm{x}) \Rightarrow \vdash \forall \mathrm{x} \alpha(\mathrm{x})
$$

Então, as afirmações existenciais $\exists \mathrm{x} \alpha(\mathrm{x})$ que são teoremas porque a subfórmula no escopo do quantificador existencial $\alpha(\mathrm{x})$ tem a forma lógica de um teorema proposicional $\alpha$, não representam qualquer problema para a generalidade absoluta da lógica clássica, já que a particularidade que elas afirmam $\exists \mathrm{x} \alpha(\mathrm{x})$ é devida a uma generalidade, uma vez que $\forall \mathrm{x} \alpha(\mathrm{x})$ também é um teorema.

Mas nem todas as afirmações existenciais que são teoremas da lógica clássica o são porque compartilham parte de sua forma lógica com um teorema proposicional. Em um sistema com identidade e constantes individuais, por exemplo, para qualquer constante ' $c$ ' a afirmação existencial $\exists \mathrm{x}(\mathrm{x}=\mathrm{c})$ é um teorema, mas a afirmação universal correspondente $\forall x(x=c)$ não é.

Este fato, no entanto, não ameaça a tese da generalidade absoluta da lógica. Apesar da forma existencial, a única particularidade da sentença $\exists x(x=c)$ é linguística, dada

${ }^{18}$ Vale notar que as afirmações existenciais são precisamente a forma lógica das sentenças que apontam os compromissos ontológicos de uma teoria. Curiosamente, a forma lógica das afirmações que exprimem os compromissos ontológicos de uma teoria é a mesma forma lógica que não poderia tomar parte em uma caracterização metafísica da realidade, o que evidencia a distinção entre metafísica e ontologia que temos assumido. A ontologia nos dá as coisas que existem, e que preenchem completamente a realidade, cujas características gerais são providas pela metafísica que, ao fazer isso, define o significado da existência. 
pela constante ' $c$ '. As sentenças com a forma $\exists x(x=c)$ afirmam apenas que uma das convenções linguísticas da lógica clássica é que todos os nomes (as constantes individuais) da linguagem denotam algum indivíduo. Se nossa linguagem tiver $\mathrm{n}$ constantes individuais $c_{1}, \ldots, c_{n}$, então para cada $(1 \leq \mathrm{i} \leq \mathrm{n})$, a sentença $\exists x\left(x=c_{i}\right)$ será um teorema que afirma que a constante ' $c_{i}$ ' denota um indivíduo. Estas sentenças, tomadas em conjunto, exprimem a convenção linguística de que as constantes individuais devem denotar. Elas, então, apenas regulam o uso das constantes individuais. A única informação que elas nos dão, para além desta convenção de nomes, é a de que a realidade não é vazia. Há seres. Este fato, no entanto, não é particular, mas geral. Ao afirmar que há seres, que a realidade não é vazia, estamos afirmando uma característica geral da realidade assumida pela lógica clássica e, portanto, respeitando a tese da generalidade absoluta.

Um modo simples de perceber que os teoremas que envolvem constantes individuais não ameaçam a tese da generalidade absoluta é mostrar que se substituirmos cada constante individual que ocorre neles por uma variável ' $y$ ' e tomarmos o fecho universal da fórmula resultante, obteremos um teorema. O teorema $\exists x(x=c)$, por exemplo, nos dá o teorema $\forall \mathrm{y} \exists \mathrm{x}(\mathrm{x}=\mathrm{y})$. De um modo geral, tanto na lógica clássica quanto na intuicionista de primeira ordem, o seguinte resultado

$$
\vdash \alpha(\mathrm{c}) \Rightarrow \vdash \forall \mathrm{y} \alpha(\mathrm{y})
$$

vale e sua demonstração em sistemas de dedução natural é um mero corolário do teorema de normalização de Prawitz (2006). Isso significa que nenhum teorema com a forma $\alpha$ (c) ameaça a tese da generalidade absoluta, porque o que eles afirmam sobre ' $c$ ' é verdadeiro para qualquer indivíduo 'y' do domínio de quantificação, já que $\forall$ y $\alpha(y)$ também é teorema. ${ }^{19}$

Vimos, até agora, que para os teoremas existenciais que têm a forma de teoremas proposicionais, vale a seguinte regra:

$$
\vdash \alpha \Rightarrow \vdash \exists \mathrm{x} \alpha(\mathrm{x}) \Rightarrow \vdash \forall \mathrm{x} \alpha(\mathrm{x})
$$

Se demonstrássemos que, independentemente da forma lógica de $\alpha$, dado um teorema existencial qualquer $\exists \mathrm{x} \alpha(\mathrm{x})$, se ao substituirmos o quantificador existencial por um universal, a fórmula resultante $\forall \mathrm{x} \alpha(\mathrm{x})$ continua sendo um teorema, então teríamos um argumento completo para a defesa generalidade absoluta da lógica. Ou seja, se demonstrássemos que, independentemente da forma de $\alpha$,

$$
\vdash \exists \mathrm{x} \alpha(\mathrm{x}) \quad \Rightarrow \quad \vdash \forall \mathrm{x} \alpha(\mathrm{x})
$$

este resultado garantiria que qualquer particularidade que pudéssemos afirmar através de um teorema existencial $\exists \mathrm{x} \alpha(\mathrm{x})$ seria apenas uma afirmação parcial de uma generalidade garantida por outro teorema, representado por $\forall \mathrm{x} \alpha(\mathrm{x})$, o que manteria assegurada a generalidade absoluta da lógica clássica.

Este resultado não é válido em geral para a lógica clássica, mas há uma prova bastante simples dele para a lógica intuicionista, que também obtém-se como um corolário do

19 Para os nossos propósitos de argumentar em favor da generalidade absoluta das lógicas clássica e intuicionista, a eliminação das constantes individuais dada pelo resultado ' $\vdash \alpha(\mathrm{c}) \Rightarrow \vdash \forall \mathrm{y} \alpha(\mathrm{y})$ ' é suficiente e será assumida nos demais argumentos desta Seção. É interessante notar também que a eliminação das constantes individuais exigida pela arregimentação na notação canônica de Quine, que as substitui por descrições, não se constitui em um problema apenas quando nos restringimos à lógica clássica. Por não comportar condicionais contrafactuais, a lógica clássica se protege das célebres críticas de Saul Kripke (2001) à abordagem descritivista dos nomes, que só se aplicam em contextos que admitem tais condicionais. Já na lógica intuicionista, esta eliminação forçada das constantes é problemática, porque a famosa tradução de Godel-McKinsey-Tarsky entre a lógica intuicionista e a lógica modal S4 demonstra a capacidade da primeira de abrigar condicionais subjuntivos e contextos contrafactuais. 
teorema de normalização. ${ }^{20}$ A lógica intuicionista é, por isso, absolutamente geral. Todos os seus teoremas que contém constantes individuais são meras afirmações parciais de teoremas universais sem constantes, e todos os seus teoremas existenciais são convertíveis em teoremas universais. Então não há, entre os teoremas da lógica intuicionista, nenhuma afirmação particular. Ela respeita a generalidade absoluta.

$\mathrm{Na}$ lógica clássica, na grande maioria dos casos em que $\exists \mathrm{x} \alpha(\mathrm{x})$ é um teorema, $\forall \mathrm{x} \alpha(\mathrm{x})$ também será, e as situações que desafiam a generalidade absoluta são bastante raras. ${ }^{21}$ Mas há exceções. A única que conheço é a seguinte sentença:

$$
\exists \mathrm{x}(\mathrm{P}(\mathrm{x}) \rightarrow \forall \mathrm{y} \mathrm{P}(\mathrm{y}))
$$

Esta sentença é um teorema da lógica clássica de primeira ordem, mas a sentença $\forall \mathrm{x}(\mathrm{P}(\mathrm{x}) \rightarrow \forall \mathrm{y} \mathrm{P}(\mathrm{y}))$, obtida pela substituição do quantificador existencial principal por um quantificador universal, não é teorema clássico. Vale notar que, como este resultado vale para a lógica intuicionista, esta exceção e qualquer outra que possa haver é uma afirmação existencial que não é teorema intuicionista. Ou seja, $\exists x(P(x) \rightarrow \forall y P(y))$ é um teorema clássico, mas não é um teorema intuicionista. Vamos comparar a afirmação existencial, que é teorema clássico, com a afirmação universal, que não é teorema, para tentar entender a situação.

$$
\begin{aligned}
& \exists x(\mathrm{P}(\mathrm{x}) \rightarrow \forall \mathrm{y} P(\mathrm{y})): \quad \begin{array}{l}
\text { há pelo menos um indivíduo que, } \\
\text { se ele for } \mathrm{P}, \text { então todos são } \mathrm{Ps} .
\end{array} \\
& \forall \mathrm{x}(\mathrm{P}(\mathrm{x}) \rightarrow \forall \mathrm{y} \mathrm{P}(\mathrm{y})): \quad \begin{array}{l}
\text { dado um indivíduo qualquer, } \\
\text { se ele for } \mathrm{P}, \text { então todos são } \mathrm{Ps} .
\end{array}
\end{aligned}
$$

Pode até parecer que a primeira sentença está fazendo uma afirmação particular sobre um indivíduo peculiar, que ela está separando a realidade e que não é absolutamente genérica. Mas quando tentamos entender por que ela é um teorema, por que não pode haver nenhuma interpretação em que ela é falsa, percebemos que apesar de sua forma existencial, ela não faz uma afirmação particular.

A segunda sentença não é um teorema clássico porque podemos conceber a circunstância em que alguns indivíduos são Ps e outros não são. Nesta circunstância, quando

${ }^{20}$ Em Veloso et al. (2012) podemos encontrar vários resultados relacionados e mais gerais do que este nosso, que apresento agora o esboço da prova: suponha que temos uma prova normal, $\pi$, de $\exists \mathrm{x} \alpha(\mathrm{x})$ em um sistema de dedução natural para a lógica intuicionista. Sendo normal, e tendo $\exists x \alpha(\mathrm{x})$ como sua última fórmula, a última regra de $\pi$ será ou uma regra de introdução do existencial $(\exists I)$ ou uma regra do absurdo intuicionista $(\perp)$. Como a lógica intuicionista é consistente, a última aplicação de regra em $\pi$ não pode ser $(\perp)$, caso contrário, se excluíssemos de $\pi$ esta última regra obteríamos uma prova do absurdo sem premissas, o que seria uma prova da inconsistência da lógica intuicionista. Então a última aplicação de regra em $\pi$ é uma aplicação de $(\exists I)$. Podemos substituir esta última aplicação de regra em $\pi$ por uma aplicação da regra $(\forall I)$, que tem exatamente a mesma forma que $(\exists I)$, obtendo uma prova $\pi^{\prime}$ cuja última sentença será $\forall x \alpha(\mathrm{x})$. Esta aplicação de $(\forall I)$ respeita as restrições da regra, porque a premissa da última regra de $\pi$ não depende de nenhuma hipótese, já que $\pi$ é a prova de um teorema (não tem hipóteses abertas) e a aplicação de $(\exists I)$ não descarta hipóteses. A prova $\pi^{\prime}$ é, então, uma prova de $\forall \mathrm{x} \alpha(\mathrm{x})$ correta e sem hipóteses abertas. Logo $\forall \mathrm{x} \alpha(\mathrm{x})$ é teorema da lógica intuicionista.

21 Como o conjunto de teoremas clássicos é infinito, falar de "grande maioria" sem nenhuma qualificação é um abuso de linguagem. Podemos entender "grande maioria" neste contexto como afirmando que para qualquer limite finito $n$ no número de símbolos das fórmulas (complexidade), o número de teoremas existenciais com complexidade menor que n cuja substituição do quantificador existencial pelo universal resulta em um teorema universal é muito maior que o número de teoremas existenciais cuja mesma substituição resulta em uma fórmula universal que não é teorema. 
instanciamos a sentença universal com um indivíduo que é $\mathrm{P}$, teremos o antecedente do condicional $\mathrm{P}(\mathrm{x})$ verdadeiro, mas o consequente $\forall \mathrm{y} \mathrm{P}(\mathrm{y})$ falso, já que estamos analisando a circunstância em que alguns indivíduos não são $P$. Então o condicional $P(x) \rightarrow \forall y P(y)$ é falso e a sentença universal $\forall x(P(x) \rightarrow \forall y \mathrm{P}(\mathrm{y}))$ também é, já que ela tem uma instância falsa.

A primeira sentença é um teorema porque tanto na circunstância em que alguns indivíduos não são Ps, quanto na circunstância em que todos são, a sentença é verdadeira. Quando alguns indivíduos não são Ps, se instanciamos o existencial com um destes indivíduos que não é $\mathrm{P}$, teremos antecedente $\mathrm{P}(\mathrm{x})$ e consequente $\forall \mathrm{y} \mathrm{P}(\mathrm{y})$ falsos, e portanto o condicional $\mathrm{P}(\mathrm{x}) \rightarrow \forall \mathrm{y} \mathrm{P}(\mathrm{y})$ será verdadeiro e o existencial $\exists \mathrm{x}(\mathrm{P}(\mathrm{x}) \rightarrow \forall \mathrm{y} \mathrm{P}(\mathrm{y}))$ também, já que tem instância verdadeira. Quando todos os indivíduos são Ps, o consequente do condicional $\forall \mathrm{y} \mathrm{P}(\mathrm{y})$ é verdadeiro e qualquer instância do existencial nos dá um antecedente do condicional $\mathrm{P}(\mathrm{x})$ também verdadeiro e portanto o condicional $\mathrm{P}(\mathrm{x}) \rightarrow \forall \mathrm{y} \mathrm{P}(\mathrm{y})$ é verdadeiro e a sentença existencial $\exists \mathrm{x}(\mathrm{P}(\mathrm{x}) \rightarrow \forall \mathrm{y} \mathrm{P}(\mathrm{y}))$ também, já que tem instância verdadeira.

Então, apesar de sua forma existencial, a sentença só é válida porque em cada uma das circunstâncias possíveis ela tem instâncias verdadeiras. As duas circunstâncias possíveis analisadas, a de que alguns indivíduos não são Ps e a de que todos os indivíduos são Ps esgotam as possibilidades. Encaradas isoladamente, cada uma destas circunstâncias representa uma situação particular, uma possibilidade específica e particular na qual os fatos podem se dar. Mas o conjunto destas duas possibilidades, ou seja, a afirmação de sua disjunção, não tem nenhuma particularidade e representa uma característica absolutamente geral da realidade, correspondendo a uma instância do terceiro excluído $(\forall \mathrm{xP}(\mathrm{x}) \vee \neg \forall \mathrm{xP}(\mathrm{x}))$.

Acontece que o reconhecimento da validade da afirmação existencial $\exists x(P(x) \rightarrow \forall y P(y))$ que apresentamos acima não nos informa qual destas duas circunstâncias possíveis é a responsável pela verdade da sentença. Há, então, dois motivos bastante distintos que justificam a verdade da sentença, e descobrir que a sentença é verdadeira não nos informa qual destes motivos é o que está em vigor. A sentença pode ser verdadeira porque alguns indivíduos não são Ps e, portanto, ela pode ser instanciada de modo que antecedente e consequente do condicional sejam falsos. Mas ela pode também ser verdadeira porque todos os indivíduos são Ps e portanto qualquer instância do existencial nos dá antecedente e consequente verdadeiros.

Apesar da sentença ter a forma lógica de uma afirmação particular que separa a realidade, como há duas circunstâncias distintas que representam dois modos distintos dela ser verdadeira, que esgotam todas as possibilidades em que os fatos podem se dar, e como o reconhecimento de sua verdade não nos diz qual dos dois é o modo pelo qual ela é verdadeira, então o reconhecimento de sua verdade não nos dá nenhuma informação particular sobre o mundo. Esta informação particular sugerida pela forma existencial da sentença só nos seria comunicada se pudéssemos saber qual das duas circunstâncias possíveis assegura a sua verdade. Como o simples fato de reconhecer a sentença como verdadeira não nos dá esta informação, e como a disjunção destas duas possibilidades é uma situação absolutamente genérica, pois esgota todos os casos, então podemos afirmar com segurança que, mesmo sendo uma afirmação existencial, sua verdade não nos informa nenhuma particularidade sobre a realidade e por isso não desafia generalidade absoluta da lógica.

Como a afirmação existencial $\exists \mathrm{x}(\mathrm{P}(\mathrm{x}) \rightarrow \forall \mathrm{y} \mathrm{P}(\mathrm{y}))$ que estamos analisando não é um teorema da lógica intuicionista, podemos ter certeza de que não é uma peculiaridade do 
argumento que apresentamos o fato de que o reconhecimento de sua validade não nos informa sobre qual de duas circunstâncias particulares possíveis é a responsável por sua verdade. Qualquer justificativa semântica para a validade desta sentença necessariamente dependerá de alguma instância do princípio do terceiro excluído, caso contrário ela seria um teorema intuicionista. Além disso, como demonstramos que na lógica intuicionista sempre que $\exists \mathrm{x} \alpha(\mathrm{x})$ é teorema, $\forall \mathrm{x} \alpha(\mathrm{x})$ também será, então qualquer outro suposto contraexemplo à generalidade absoluta que viermos a encontrar será semelhante a este, no sentido de que o reconhecimento de sua validade dependerá do princípio do terceiro excluído e, portanto, não desafiará a generalidade absoluta da lógica pelos mesmos motivos que apresentamos para o caso atual.

Podemos finalmente concluir que, mesmo possuindo certos teoremas existenciais cujas contrapartidas universais não são teoremas, a lógica clássica, tanto quanto a lógica intuicionista, respeita o princípio da generalidade absoluta. Nenhum de seus teoremas faz qualquer afirmação particular. Eles não dividem nem separam a realidade. Não se referem a características específicas de indivíduos específicos, mas apenas a características gerais de todos os indivíduos e constituem-se, por isso, em princípios metafísicos que nos dão uma caracterização da estrutura mais geral da realidade.

Conforme já comentamos, não é possível dar um argumento único para a generalidade absoluta de todos os sistemas lógicos, simplesmente porque não há consenso entre os lógicos sobre os limites do seu domínio de conhecimento. Além de argumentos como estes que apresentei sobre a generalidade absoluta de sistemas lógicos específicos, o máximo que podemos almejar é um resultado que nos informaria, por exemplo, quais as características formais genéricas que os sistemas lógicos deveriam ter de modo a respeitar a generalidade absoluta. Esta interessante tarefa está, no entanto, muito além dos propósitos deste texto.

Com a discussão dos debates entre realismo x idealismo apresentada na Seção 5, vimos um exemplo de aplicação bem-sucedida do critério da incompatibilidade lógica. Ou seja, uma aplicação do critério em que a incompatibilidade lógica das posições adversárias nos mostrou que a divergência ali tratada é uma divergência metafísica genuína. Apenas a título de exemplo, antes de passarmos às considerações finais vamos, na próxima Seção, discutir brevemente um caso em que a aplicação do critério da incompatibilidade lógica demonstra que a posição dissidente defendida por um dos lados não é, nos termos em que foi proposta por seu autor, uma dissidência metafísica legítima, caracterizando a divergência como meramente verbal.

\section{McDaniel $x$ van Inwagen: a univocidade do ser}

Em "Ways of Being", Kris McDaniel (2009) apresenta uma defesa do que ele considera ser a versão heideggeriana da tese de que a existência não é unívoca. Haveria, para Heidegger, múltiplos modos de ser: "there are many things which we designate as 'being', and we do so in various senses" (Heidegger, 1993, 26). McDaniel aponta rapidamente algumas raízes históricas da tese e propõe uma interpretação para a versão heideggeriana na qual os múltiplos modos do ser são identificados através da equivocidade de significados presente em nossos usos de expressões como "ser", "existência", "existe", "é uma entidade", "há". Ele classifica estas expressões como analógicas, e define: uma expressão é analógica quando "ela tem um sentido genérico que, a grosso modo, aplica-se a objetos de diferentes tipos em virtude destes objetos exemplificarem características bastante diferentes" (McDaniel, 2009, 295). Ele apresenta a expressão mereológica "é uma parte de" como um modelo paradigmático de expressão analógica e exemplifica alguns de seus usos: 
esta mão é uma parte deste homem, a classe das mulheres é uma parte da classe dos seres humanos, esta sub-região é uma parte do espaço, este minuto é uma parte desta hora, esta premissa é uma parte deste argumento, e assim por diante. (McDaniel, 2009, 295)

Para McDaniel há uma ideia comum a estes vários usos, mas não é esta ideia comum que explica e justifica cada um deles. Cada uso específico aplica-se a objetos de tipos muito distintos e é explicado por uma relação fundamental específica. Cada uma destas relações fundamentais representa um conceito distinto do que é ser uma parte que é particular ao tipo de coisas às quais ela se aplica. Portanto, os motivos pelos quais há partes em cada caso são também fundamentalmente diversos (p. 296). Ou seja, "ser uma parte de" é uma expressão analógica para McDaniel porque haveria diversos modos muito variados em que algo é parte de algo. Da mesma forma, nossos múltiplos usos das expressões ligadas aos seres exprimiriam o fato de que há muitos modos de ser, e o conceito de ser também seria analógico. Usarei a expressão 'tese da equivocidade' para me referir à posição de McDaniel.

Na outra ponta da divergência que nos interessa aqui está Peter van Inwagen, que defende a tese contrária de que a existência é unívoca, não havendo múltiplos modos de ser, mas um único. Para van Inwagen, o conceito de ser não seria analógico e qualquer coisa que exista, existe exatamente do mesmo modo e no mesmo sentido do que qualquer outra. Usarei a expressão 'tese da univocidade' para me referir à posição de van Inwagen.

A divergência entre as teses da univocidade e da equivocidade é, aparentemente, uma divergência metafísica sobre se na estrutura geral da realidade há lugar para diferentes modos de existir, ou se a realidade comporta apenas um modo de existir. Nosso objetivo aqui é aplicar o critério da incompatibilidade lógica para mostrar que, do modo específico como estes dois autores a tratam, esta não é uma divergência metafísica legítima, mas apenas um desacordo meramente verbal entre os adversários. Mas neste caso específico, o critério nos ajudará também a perceber que a causa deste desacordo verbal é um mau uso das palavras feito pelos defensores da tese da equivocidade. Veremos que o vocabulário que McDaniel importa de Heidegger sobre os muitos modos de ser é inadequado e enganoso.

Feitos estes esclarecimentos preliminares, apresentarei, a seguir, um breve resumo da tese da univocidade conforme defendida por van Inwagen (2009) em "Being, Existence, and Ontological Commitment" e os principais pontos da tese da equivocidade, defendida por McDaniel (2009) em "Ways of Being". Em seguida apresentarei a crítica à tese da equivocidade que o próprio van Inwagen (2014) faz, em "Modes of Being and Quantification", onde ele realiza uma arregimentação formal da tese da equivocidade na lógica clássica de primeira ordem, a mesma lógica em que ele arregimenta a sua própria tese da univocidade. Isso torna possível empregar o critério da incompatibilidade lógica e concluir que o desacordo não é genuinamente metafísico. Ao final esclarecemos quais as conclusões que podemos tirar desta análise.

Em "Being, Existence, and Ontological Commitment", van Inwagen apresenta o modo como ele entende que a ontologia deveria ser praticada e quais suas teses fundamentais. Ele afirma que estas teses representam o modo como Quine entende as questões ligadas ao ser e as rotula de "5 teses da meta-ontologia de Quine":

T1) O ser não é uma atividade.

T2) Ser e existência são o mesmo.

T3) A existência é unívoca. 
T4) O único sentido do ser ou existência é adequadamente capturado pelo quantificador existencial da lógica formal.

T5) As questões ontológicas devem ser resolvidas através do método do compromisso ontológico.

Se ser e existência são o mesmo, então falar sobre univocidade ou equivocidade do ser, ou sobre um único ou múltiplos modos de existir é a mesma coisa. Além disso, se a existência é unívoca e o seu único sentido é capturado pelo quantificador existencial, então há um único e irrestrito domínio de quantificação que abrange tudo o que há, e as regras lógicas, que regulam o quantificador existencial, esgotam as possibilidades para o significado da existência. Estas teses o autorizam a concordar com a afirmação de Quine de que "a existência é o que o quantificador existencial expressa. Há coisas do tipo $F$ se e somente se $\exists x F(x) "$ (Quine, 1969, 97).

Além disso, como, de acordo com T5, van Inwagen aceita o método ontológico de Quine que apresentamos na Seção 3, então a lógica formal a que ele se refere na tese $T 4$ é a lógica clássica de primeira ordem. Ou seja, o quantificador existencial que captura o sentido único da existência é para van Inwagen o existencial da lógica clássica de primeira ordem.

A tese da univocidade, de acordo com van Inwagen, resume-se, então, na aceitação de que é na lógica clássica de primeira ordem que devemos arregimentar nossas teses sobre o ser, que há um único e irrestrito domínio de quantificação, que é acessado pelo quantificador existencial, cujas regras capturam o sentido único da existência.

Voltemo-nos agora para a tese da equivocidade. Vou me concentrar apenas nos pontos cruciais suficientes para o entendimento do debate, omitindo vários de seus aspectos e detalhes que não são relevantes para a nossa questão. Após as explicações iniciais sobre o significado mais geral da ideia da equivocidade do ser e de vários esclarecimentos paralelos, McDaniel esforça-se por explicar a posição de Heidegger sobre a equivocidade através de recursos formais como predicados, quantificadores e variáveis. Ele afirma que apesar de Heidegger defender que "o ser vem em muitos sabores", ele reconhece que há um sentido genérico de ser. E afirma que "o sentido genérico de ser é representado na lógica formal pelo quantificador irrestrito" padrão da lógica de primeira ordem (McDaniel, 2009, 301).

Então ele se pergunta: "qual é a melhor forma de representar os diversos sentidos restritos do ser segundo Heidegger?" Após rapidamente recusar o uso de constantes individuais para esta tarefa, ele considera a possibilidade de predicados especiais representarem os diversos modos de ser. Mas também aqui descarta rapidamente esta possibilidade: "isto parece inapropriado, uma vez que este procedimento trata a atribuição de um modo de ser a uma coisa como a predicação de uma propriedade desta coisa". E continua: "os modos do ser não são meras propriedades especiais que algumas entidades têm e que outras carecem, e por isso não são representados do modo mais perspicaz por predicados" (p. 302). E faz, na sequência, sua sugestão crucial:

uma ideia natural, então, é que os sentidos específicos de 'ser' são melhor representados por quantificadores. A noção de um quantificador restrito - um que varia sobre apenas algum subconjunto próprio do que o quantificador irrestrito varia - é perfeitamente inteligível. Os sentidos do 'ser' de Heidegger são propriamente representados em um sistema formal por quantificadores restritos. [...] Então para cada tipo especial de ser reconhecido por Heidegger, corresponde um quantificador restrito cujo domínio é uma subclasse própria do domínio do quantificador irrestrito, e que varia sobre todas e apenas aquelas coisas que têm este tipo de ser (p. 302). 
Logo em seguida ele faz a seguinte estranha declaração.

Então representar os modos de ser de Heidegger através de quantificadores restritos - quantificadores que em virtude de seu significado variam apenas sobre algum subconjunto próprio do que o quantificador existencial irrestrito varia parece um modo excelente de proceder. (pp. 302-303)

A estranheza aqui está na afirmação de que os quantificadores restritos são restritos em virtude de seu significado. A pergunta imediata que esta afirmação suscita é: o que é o significado de um quantificador? Onde, por quem e como ele é estabelecido? A única indicação de alguma resposta para esta questão que seu texto traz é uma citação de Eli Hirsch $(2005,76)$, em que ele afirma que os quantificadores seriam semanticamente restritos quando "regras semânticas implícitas na linguagem" estabelecem a restrição de seu domínio (McDaniel, 2009, 303). Mas McDaniel ignora esta sugestão e deixa completamente sem resposta a questão sobre como os quantificadores adquirem o significado que eles têm.

Mas continuemos por ora. Ele então propõe, para exemplificar, dois tipos de quantificadores restritos, o que ele chama de 'existenzial', cujo domínio de quantificação são as entidades cujo modo de ser é ter existenz, que é o modo de ser das coisas concretas e particulares. O outro quantificador é o que ele chama de 'subsistential', cujo domínio são as entidades que têm subsistência como o seu modo de ser, que é o modo de ser das coisas abstratas. E ele insiste que é em virtude do significado de cada um destes quantificadores que seu domínio de quantificação é especificado (p. 303).

Temos então três tipos de quantificadores existenciais, o quantificador existencial genérico da lógica clássica, cujo domínio de quantificação é absolutamente genérico, e os quantificadores restritos existenzial e subsistential, com seus domínios de quantificação restritos aos tipos de seres concretos e abstratos a que eles respectivamente se ligam.

McDaniel alega que, de acordo com a perspectiva de Heidegger, os quantificadores restritos existenzial e subsistential devem ser prioritários em significado com relação ao quantificador existencial genérico (p. 303). Então ele afirma que, sendo prioritários em significado em relação ao quantificador irrestrito, os quantificadores restritos devem ser semanticamente primitivos, e passa a investigar como usar estes quantificadores para entender de que modo o sentido genérico do ser, que é subsidiário dos sentidos restritos, poderia deles ser obtido. Para esta discussão ele apela ao conceito de fundamentalidade.

Esta discussão, do modo que ele a apresenta, me parece apressada e mal formulada. Sua conclusão é também meramente negativa. Ele não apresenta nenhum argumento positivo para suportar sua posição sobre a prioridade de significado dos quantificadores restritos relativamente ao genérico, mas apenas uma defesa a um argumento contrário a esta tese. Ainda que esta defesa seja bem sucedida, o problema de sua abordagem que propiciou a crítica de van Inwagen é o fato de que, para além da mera afirmação de que há diferentes modos de ser, e da nomeação de alguns destes modos, ele não diz uma palavra sequer que explique, demonstre ou esclareça em que consiste a distinção dos múltiplos modos de ser. Se a existência abstrata dos seres que subsistem é diferente da existência concreta dos seres que existem, em que consiste esta diferença? Para além de pertencerem a domínios de quantificação distintos, quais as características que distinguem estes dois domínios de quantificação? O que é permitido (ou possível) a seres de um tipo que é proibido (ou impossível) a seres de outro? Qual a motivação para esta separação entre os diferentes modos de ser e em que ela consiste? Não há uma palavra sequer esclarecendo estas questões no texto de McDaniel. 
Esta ausência de qualquer esclarecimento sobre de que modo os múltiplos modos de ser são diferentes uns dos outros propiciou combustível para a crítica da tese de McDaniel da equivocidade do ser que van Inwagen (2014) elaborou em "Modes of Being and Quantification". Ele aproveitou-se desta indefinição e propôs variadas maneiras de arregimentar a tese da equivocidade na lógica clássica de primeira ordem. Algumas utilizando uma versão polissortida da lógica de primeira ordem e interpretando os modos de ser através de quantificadores restritos, exatamente de acordo com as prescrições de McDaniel (van Inwagen, 2014, 20). Algumas outras, no entanto, formalizando os modos de ser não como quantificadores, mas como predicados cujas extensões coincidiriam com os seres de cada suposto modo (van Inwagen, 2014, 9). ${ }^{22}$

O ponto central de sua argumentação foi mostrar que qualquer argumento que fosse informalmente válido (ou inválido) quando avaliado de modo a respeitar a tese da equivocidade, continuaria válido (ou inválido) em qualquer de suas arregimentações na lógica clássica de primeira ordem. Se a este fato acrescentarmos a sua abordagem à ontologia, na qual o sentido único da existência é capturado pelo quantificador existencial geral da lógica clássica, então estas suas arregimentações representam uma prova de que a tese da equivocidade não afirma nada substancial, já que ela é compatível com a tese da univocidade. Ao possuir arregimentações na lógica clássica de primeira ordem que se comportam exatamente como a versão original não arregimentada, a tese da equivocidade se mostra compatível com a tese da univocidade, uma vez que o quantificador existencial único da lógica clássica exprime e representa a própria tese da univocidade, de acordo com van Inwagen. O fundamento da crítica de van Inwagen é, então, o caráter inerte da proposta de McDaniel.

Van Inwagen não menciona explicitamente nada semelhante ao nosso critério da incompatibilidade lógica, nem tampouco compromete-se com nossa hipótese do isomorfismo entre lógica e metafísica. Mas podemos "sentir o cheiro forte" do critério da incompatibilidade lógica aqui. Ele entende sua própria argumentação como uma vitória da tese da univocidade sobre a equivocidade, vitória esta propiciada por suas arregimentações compatíveis com a versão original não arregimentada da equivocidade com relação aos argumentos que elas validam ou invalidam.

A nossa interpretação da situação, dada pelo critério da incompatibilidade lógica é, no entanto, suavemente diferente. Nós não precisamos, em princípio, assumir a tese inwageriana de que um dos compromissos metafísicos da lógica clássica de primeira ordem é a univocidade do ser. A controvérsia sobre a generalidade absoluta do domínio de quantificação da lógica clássica presente na literatura (Rayo and Uzquiano, 2009) nos sugere cautela neste quesito. Na ausência desta suposição, as arregimentações de van Inwagen demonstram apenas que as teses da univocidade e da equivocidade são logicamente compatíveis e, portanto, pelo critério da incompatibilidade lógica, a divergência entre elas não corresponde a uma divergência metafísica genuína sobre a estrutura mais geral da realidade. É esta a informação principal que a aplicação de nosso critério a este debate nos dá. No entanto, quando colocamos lado a lado o discurso e vocabulário heideggeriano ligado à tese da equivocidade e o discurso e vocabulário quineano da tese da unicidade, e os confrontamos com os compromissos metafísicos mais óbvios que a lógica clássica de primeira ordem parece assumir, fica muito difícil discordar de van Inwagen.

\footnotetext{
${ }^{22}$ Como a lógica clássica polissortida é traduzível na lógica clássica com um único tipo de variável, então todas as arregimentações de van Inwagen da tese da equivocidade de McDaniel são equivalentes e compatíveis com a lógica clássica de primeira ordem tradicional.
} 
Talvez haja razões para rejeitar também a tese da univocidade de van Inwagen, por causa de argumentos ligados à generalidade absoluta dos quantificadores ou outro motivo qualquer. No entanto, mesmo que venhamos a descobrir que a existência não é unívoca, a presente análise nos autoriza a afirmar com segurança que ainda que haja múltiplos modos de ser, não será a versão de McDaniel da tese da equivocidade de Heidegger que nos fornecerá a explicação deste fato.

\section{Considerações Finais}

A proposição do critério da incompatibilidade lógica foi motivada por dois tipos de preocupações: metafísicas e lógicas. Do lado da metafísica, minha preocupação primeira foi defender a disciplina dos ataques deflacionistas que ela sempre sofreu tanto do senso comum, quanto de cientistas e também de filósofos. Mas do mesmo modo que considero injustificados estes ataques, também sempre me incomodou o fato de que muitas propostas e debates metafísicos específicos presentes na literatura parecem dar razão aos deflacionistas. Refletir sobre a estrutura geral da realidade é uma atividade arriscada, escorregadia, traiçoeira e em muitos casos específicos os filósofos parecem tropeçar em suas próprias palavras e perderem-se em considerações incoerentes, intuições esdrúxulas e debates estéreis.

Do lado da lógica, sempre me intrigou o fato que todas as nossas justificativas lógicas se fundam em princípios que não são, eles próprios, justificados. O que fundamentaria os princípios lógicos? Qual a razão para o fato de que quando os aplicamos corretamente eles nos levam a conclusões confiáveis?

A hipótese do isomorfismo entre lógica e metafísica e o critério da incompatibilidade lógica para as divergências metafísicas representam a minha resposta a estas inquietações. Os princípios lógicos são confiáveis porque eles configuram-se em uma expressão da estrutura geral da realidade. São prescrições para o pensamento correto, conforme nos ensina Frege, porque são leis que estabelecem o que é, em seu aspecto mais geral. Os princípios lógicos, são lógicos, porque são princípios metafísicos.

As propostas metafísicas, por seu turno, enquanto caracterizações da estrutura mais geral da realidade, são, por isso, imagens supervenientes dos princípios lógicos. Vinculamse a eles tanto quanto as figuras geométricas vinculam-se aos gráficos cartesianos de suas equações algébricas. Então aquelas propostas supostamente metafísicas, mas que não possuem qualquer especificidade lógica, não são genuinamente metafísicas. E as propostas genuinamente metafísicas não são estéreis, são, ao contrário, férteis. Porque ao possuírem especificidade lógica elas se espalham e influenciam todos os demais assuntos sobre os quais raciocinamos. Ao influenciarem e afetarem todos os assuntos sobre os quais raciocinamos, elas assumem o papel central que se espera de uma caracterização geral da realidade. As propostas metafísicas, são metafísicas, porque são lógicas. 


\section{Referências Bibliográficas}

Aristotle and Richard McKeon. The Basic Works of Aristotle. Random House, New York, 1941.

Francesco Berto and Matteo Plebani. Ontology and Metaontology: a contemporary guide. Bloomsbury Publishing, London, 2015.

Rudolf Carnap. The Logical structure of the world: pseudoproblems in philophy. University of California Press, Berkeley and Los Angeles, 1969.

Oswaldo Chateaubriand. Logical Forms, volume 34 of Coleção CLE. UNICAMP, Centro de Lógica, Epistemologia e História da Ciência, Campinas, 2001. Part I - Truth and Descriptions.

Itala D'Ottaviano and Hércules Feitosa. Sobre a história da lógica, a lógica clássica e o surgimento das lógicas não-clássicas. 2003. URL ftp://ftp.cle.unicamp.br/pub/arquivos/educacional/ArtGT.pdf.

Michael Dummett. Realism. In Truth and Other Enigmas, pages 145-165. Harvard University Press, Cambridge, 1978.

Michael Dummett. The Logical Basis of Metaphysics. Harvard University Press, Cambridge, 1991.

Daniel Durante. Logic is metaphysics. Principia, 15(1):31-42, 2011.

Daniel Durante. Compromisso ontológico. In J. Branquinho and R. Santos, editors, Compêndio em Linha de Problemas de Filosofia Analítica, pages 1-39. LanCog - Universidade de Lisboa, 2014.

Hartry Field. Science Without Numbers. Oxford University Press, Oxford, 2016.

Gottlob Frege and Montgomery Furth. [Grundgesetze der Arithmetik.] The basic laws of arithmetic; translated and edited, with an introduction, by Montgomery Furth. Cambridge University Press, Berkeley and Los Angeles, 1967.

Martin Heidegger. Being and Time. Harper Collins Press, New York, 1993.

Eli Hirsch. Physical-object ontology, verbal disputes, and common sense. Philosophy and Phenomenological Research, 70(1):67-97, 2005.

Edmund Husserl. Logical investigations. Routledge, Bury St Edmunds, 2015.

Saul A. Kripke. Naming and Necessity. Harvard University Press, Cambridge, 2001.

Kris McDaniel. Ways of being. In David Chalmers, David Manley, and Ryan Wasserman, editors, Metametaphysics: new essays on the foundations of ontology, pages 290-319. Oxford University Press, Oxford, 2009.

Dag Prawitz. Natural Deduction: a proof-theoretical study. Dover Publications, Mineola, N.Y., 2006.

Willard van O. Quine. From a Logical Point of View. Harper Torchbooks, New York, 1963a.

Willard van O. Quine. Logic and The Reification of Universals. In From a Logical Point of View Quine (1963a), pages 102-129.

Willard van O. Quine. On what there is. In From a Logical Point of View Quine (1963a), pages $1-19$. 
Willard van O. Quine. Existence and Quantification. In Ontological Relativity and Other Essays, pages 91-113. Columbia University Press, New York, 1969.

Agustín Rayo and Gabriel Uzquiano. Absolute generality. Clarendon, Oxford, 2009.

Gonçalo Santos. Numbers and Everything. Philosophia Mathematica, 21(3):297-308, 2013.

Robin Smith. Aristotle's logic. In Edward N. Zalta, editor, The Stanford Encyclopedia of Philosophy. Metaphysics Research Lab, Stanford University, summer 2019 edition, 2019.

Tuomas E. Tahko. An Introduction to Metametaphysics. Cambridge University Press, Cambridge, MA, 2015.

Alfred Tarski. The semantic conception of truth and the foundations of semantics. Philosophy and phenomenological research., 4(3), 1944.

Peter van Inwagen. Being, Existence, and Ontological Commitment. In David Chalmers, David Manley, and Ryan Wasserman, editors, Metametaphysics: new essays on the foundations of ontology, pages 472-506. Oxford University Press, Oxford, 2009.

Peter van Inwagen. Modes of being and quantification. Disputatio, 6(38):1-24, 2014.

Paulo Veloso, Luiz Carlos Pereira, and Hermann Haeusler. On what there must be: existence in logic and some related riddles. Disputatio. Logic, Norms and Ontology., 4 (34):889-910, 2012.

Timothy Williamson. Modal logic as metaphysics. Oxford University Press, Oxford, 2015. Ludwig Wittgenstein. Tractatus logico-philosophicus. Routledge, Oxfordshire and New York, 2014. 